\title{
Enhancement of active ingredients and biological activities of Nostoc linckia biomass cultivated under modified BG-11, medium composition
}

\author{
Eman A. El-fayoumy ${ }^{1} \cdot$ Sanaa M. Shanab ${ }^{1} \cdot$ Omnia M. A. Hassan $^{2} \cdot$ Emad A. Shalaby $^{3}$ \\ Received: 26 February 2021 / Revised: 6 April 2021 / Accepted: 9 April 2021 \\ (C) The Author(s), under exclusive licence to Springer-Verlag GmbH Germany, part of Springer Nature 2021
}

\begin{abstract}
The current work aims to investigate the effect of abiotic stresses (nitrogen (N) and sulfur (S) [0.0 g/l, $1.5 \mathrm{~g} / 1,3 \mathrm{~g} / 1,6 \mathrm{~g} / 1$, and $12 \mathrm{~g} /$ $1 \mathrm{~N}$ and $0.0 \mathrm{~g} / 1,0.07 \mathrm{~g} / 1,0.15 \mathrm{~g} / 1,0.3 \mathrm{~g} / 1$, and $0.6 \mathrm{~g} / 1 \mathrm{~S}]$ and their combination $[0.3 \mathrm{~g} / 1 \mathrm{~S}+6 \mathrm{~g} / 1 \mathrm{~N}]$ ) of axenic culture of Nostoc linckia on the production of secondary metabolites which induce different biological activities. Growth rate was measured by dry weight (DW) and optical density $(\mathrm{OD})_{550 \mathrm{~nm}}$. Additionally, phytochemical compounds, defense enzymes as well as antioxidant activity against 2,2-diphenyl-1-picrylhydrazyl (DPPH) and 2,2'-azino-bis(ethylbenzthiazoline-6-sulfonic acid) (ABTS ${ }^{+}$) radical assays of crude extracts (methylene chloride:methanol, 1:1) were evaluated. Based on antioxidant activity, four promising extracts were subjected to different biological activities such as anticancer, antimicrobial, and antiviral activities. The obtained results revealed that supplementation of external nitrogen source in the form of sodium nitrate was found to increase the total phycobiliprotein content by fivefold. Also, nitrogen depletion provoked significantly highest quantities of phenolic and flavonoid content and this has effects on biological activities of Nostoc linckia. Moreover, $0.3 \mathrm{~g} / \mathrm{l} \mathrm{S}$ was found to be the most effective extract exhibiting a significant increase in antioxidant activity based on DPPH and ABTS assays, respectively $(88.18 \pm 0.64 \%$ and $84.20 \pm 1.01 \%$ ). Furthermore, it recorded anticancer activity against HCT 116 cell line with $\mathrm{IC}_{50}$ of $155 \mu \mathrm{g} / \mathrm{ml}$. Moreover, this extract possessed a noticeable antibacterial potency (21.0 \pm 1.0 as $\mathrm{mm}$ inhibition zone against Staphylococcus aureus and $19.3 \pm 0.6$ against Streptococcus mutans). In addition, its antiviral activity against $\mathrm{H}_{5} \mathrm{~N}_{1}$ virus as a percentage of inhibition was $50 \%$ and $63.6 \%$ at a concentration of $7 \mu \mathrm{g} / \mathrm{ml}$ and $28 \mu \mathrm{g} / \mathrm{ml}$, respectively, with cytotoxicity less than $7 \mu \mathrm{g} / \mu \mathrm{l}$. GC-MS analysis recorded the presence of bioactive compounds exhibiting different biological activities. Therefore, the obtained results can represent valuable bioactive compounds with variable biological potencies.
\end{abstract}

Keywords Cyanobacteria $\cdot$ Nostoc linckia $\cdot$ Phytochemicals $\cdot$ Antioxidant $\cdot$ Anticancer $\cdot$ Antiviral $\cdot$ Defense enzymes $\cdot$ GC-MS analysis

\section{Introduction}

Cyanobacteria are a wide group including approximately 150 genera and 2000 species [1,2]. A large heterogeneity among the genera provides the opportunity for the production of

Emad A. Shalaby

dremad2009@yahoo.com

1 Department of Botany and Microbiology, Faculty of Science, Cairo University, Giza 12613, Egypt

2 Center of Scientific Excellence for Influenza Virus, Environmental Research Division, National Research Center, Dokki, Egypt

3 Department of Biochemistry, Faculty of Agriculture, Cairo University, Giza 12613, Egypt different secondary metabolites with applications in many aspects of people's lives. These applications vary from biofuels $[3,4]$, nutrition [5, 6], and biofertilizers [7] to cosmeceuticals and pharmaceuticals [8].

The potential of cyanobacteria as novel sources of valuable chemicals and other products is gaining interest worldwide. In the last few decades, microalgae have become the focus for extensive screening of novel compounds with interesting biological activities [9-12], in addition to the pharmacologically active algal secondary metabolites such as phenolics, terpenes, and carotenoids that are associated with their biological activities as antioxidant, anticancer, biofuel, and antiviral against influenza virus and could be promising as anti-coronavirus (SARS-CoV-2) as reported by Shalaby et al. [13], Carpine and Sieber [14], and Priya and Ramesh [15]. 
Stress involves the disruption of homeostasis as a result of a stressor application. The stress responses are the changes in the cell metabolism as the cells acclimatize and attempt to restore the homeostasis. The different stages in stress responses are alarming stage, regulation, acclimation, and adaptation [16]. Stress strategies have been adopted to enhance high-value compound production using single stress factor such as the nutritional factors (e.g., carbon source, nitrogen, phosphorus) and environmental factors (high light intensities, temperature, $\mathrm{pH}$, salinity, reactor configurations, and operating conditions) [17-19].

Nitrogen and sulfur represent, for all algal cells, essential macronutrients, so their deficiency triggers a variable range of metabolic responses in algae and higher plants. However, cyanobacteria are considered as a valuable support for investigating the effects of nutrient limitation due to their rapid growth, high reproduction rate, and simple culture system of experimentation.

Sulfur represents an essential macronutrient that is needed for growth and survival of all microalgae and cyanobacteria. Living organisms that depend on sulfur for synthesis and modification of different biomolecules including iron-sulfur proteins (ferredoxins), protein, and the cofactors thiamine, biotin, thiouridine, and lipoic acid [20]. Sulfur deficiency induces an imbalance between nitrogen and carbon. The dramatic reduction in phosphoenolpyruvate carboxylase activity proposed that carbon was diverted away from anaplerosis and possibly channeled into $\mathrm{C} 3$ metabolism [21]. Moreover, as a macroelement, $\mathrm{N}$ is very important mineral for microalgal metabolism and its deprivation is compensated by radical changes in the metabolic pathways. As a response to the increased ROS level, microalgae may accumulate antioxidant compounds such as polyphenols, flavonoids, and carotenoids to quench the free radicals $[22,23]$.

There is no evidence of how the manipulation of the growth conditions influences the phytochemical and biological activities. Hence, the current study focused on the effect of $\mathrm{N}$ and $\mathrm{S}$ concentrations and their combination on the phytochemical (phenolic, flavonoid, tannin, and proline) content as well as defense enzymes and pharmacological (antioxidant, anticancer, antimicrobial, and antiviral) activities of Nostoc linckia. Moreover, the chemical composition of promising extract $(0.3 \mathrm{~g} / \mathrm{l} \mathrm{S})$ was analyzed using gas chromatographymass spectrometry (GC-MS) analysis.

\section{Materials and methods}

\subsection{Materials}

\subsubsection{Chemicals and reagents}

Pure hexane, chloroform, ethanol, ether, acetone, methanol, and methylene chloride were purchased from E.
Merck Co. (Darmstadt, Germany). Sulforhodamine, 2,2-diphenyl-1-picrylhydrazyl (DPPH), and 2,2'-azinobis(ethylbenzthiazoline-6-sulfonic acid) $\left(\mathrm{ABTS}^{+}\right)$were purchased from Sigma-Aldrich (St. Louis, MO, USA). Trichloroacetic acid and other materials were of the highest available commercial grade. Gallic acid, butylated hydroxytoluene (BHT), rutin, tannic acid, L-proline, and vitamin $\mathrm{C}$ were purchased from Sigma-Aldrich (St. Louis, MO, USA).

\subsubsection{Algal cultivation}

The blue green microalga Nostoc linckia used in this study was kindly isolated in Phycology Lab. and identified by Dr. Sanaa Shanab, Professor of Phycology in the Department of Botany and Microbiology, Faculty of Science, Cairo University, according to Prescott [24].

In brief, alga was isolated from the soil at both sides of water stream of Helwan hot water spring in 2005. The ground air-dried soil was sieved (mesh no. 30). One gram of the soil was mixed with $99 \mathrm{ml}$ of distilled water and shaken for $2 \mathrm{~h}$, and $1 \mathrm{ml}$ of the soil water extract was inoculated on autoclaved solid agar basal bold medium and incubated at $25{ }^{\circ} \mathrm{C}(37.5$ $\mu$ mol-1m2 sec-1, 16/8 L/D cycles).

The separated algal colonies were examined by a light microscope, and the process was repeated several times till the isolated spot was unialgal. Transfer to liquid nutritive medium, purified from bacteria by a mixture of antibiotics (for this study), was performed to obtain an axenic culture ready to be used in experiments according to the method described by Andersen [25].

Trichomes of Nostoc linckia (Roth) Bornet and Flah were characterized by firm outer tegument of homogenous mucilage that encloses numerous coiled threads of bead-like cells with intercalary heterocysts and terminal akinetes. It occurs as minute blue balls in soft water lakes or on the downstream side of rocks or on damp soils.

The alga was maintained in standard conditions at $25 \pm 1$ ${ }^{\circ} \mathrm{C}$ in BG- $11_{0}$ medium, under fluorescent white light (Philips, TLD18W/54-765) of intensity of $40 \mu \mathrm{mol} / \mathrm{m}^{2} / \mathrm{s}$ and light duration of 16/8 L/D cycles, with constant bubbling of air (filtered through a $0.22-\mu \mathrm{m}$ microporous filter) as reported by Elfayoumy et al. [10].

\subsubsection{Antioxidant enzyme kits}

Catalase enzyme (biodiagnostic) It is an antioxidant enzyme used against $\mathrm{H}_{2} \mathrm{O}_{2}$ which causes intracellular damage.

The kit include the following: (1) phosphate buffer of pH $7(100 \mathrm{mM} / \mathrm{l})$, (2) $\mathrm{H}_{2} \mathrm{O}_{2}$ substrate as standard (500 $\mathrm{mM} / \mathrm{l})$, (3) chromogen inhibitor, and (4) enzyme peroxidase $(>2000 / 1)$ and 4-aminoantipyrine preservative (2 $\mathrm{mM} / \mathrm{l})$. 
Glutathione S-transferase (biodiagnostic) They are multifunctional enzymes which play a key role in cellular detoxification. The enzymes protect cells against toxicants by conjugating them to glutathione and neutralizing their electrophilic sites.

Glutathione $S$-transferase (GST) kit measures total GST activity by recording the absorbance at $340 \mathrm{~nm}$.

\subsubsection{Lipid peroxidation (malondialdehyde) (biodiagnostic)}

Thiobarbituric acid (TBA) react with malondialdehyde (MDA) in acidic medium at $95{ }^{\circ} \mathrm{C}$ for $30 \mathrm{~min}$ to form thiobarbituric acid-reactive product determined spectrophotometrically by absorbance at $534 \mathrm{~nm}$ (of the pink product).

The kit includes the following: (1) standard $(10 \mathrm{nmol} / \mathrm{ml})$ and (2) thiobarbituric acid detergent stabilizer (25 $\mathrm{mmol} / \mathrm{l})$.

\subsubsection{Cell line cultures (for anticancer activity)}

A human lung cancer cell line (A549) was propagated in Dulbecco's modified Eagle's medium (DMEM) highglucose medium (DMEM High Glucose w/ stable Glutamine w/ Sodium Pyruvate, Biowest), and human breast adenocarcinoma (MCF-7), human colorectal carcinoma (HCT 116), and human cervical cancer (HeLa) were propagated in RPMI 1640 L-glutamine medium (Lonza Verviers SPRL, Belgium, cat\# 12-604F); both media were supplemented with $10 \%$ fetal bovine serum (FBS) (Seralab, UK, cat\# EU-000-H) and $1 \%$ antibiotic (Antibiotic antimycotic, Biowest, cat\#L0010). The cells were incubated in 5\% $\mathrm{CO}_{2}$ humidified at $37{ }^{\circ} \mathrm{C}$ for growth. The cell lines were obtained and propagated in the center for genetic engineering (Faculty of Medicine, Al Azhar University, Egypt).

\subsubsection{Antimicrobial activity}

Bacterial and fungal cultures All experiments were conducted at Biochemistry Central Laboratory, Department of Chemistry, Faculty of Science, Cairo University, Giza, Egypt.

For determination of antimicrobial activity of different algal extracts, it was tested in vitro against G+ve and $G-v e$ bacterial strains using agar well diffusion method. The Gram-positive bacterial strains (Staphylococcus aureus [ATCC: 6538] and Streptococcus mutans [ATCC: 25175]) and the Gram-negative strains (Escherichia coli [ATCC: 9637] and Klebsiella pneumoniae [ATCC: 10031]) were cultured using the Luria-Bertani agar medium and incubated at $37{ }^{\circ} \mathrm{C}$ for $24 \mathrm{~h}$.

Fungal strain used in this study was Aspergillus niger (ATCC: 32856) and the yeast, Candida albicans (ATCC: 10231). Fungal species were cultured on the Sabouraud Dextrose Broth medium and incubated at $27^{\circ} \mathrm{C}$ for 7 days.

\subsubsection{Antiviral activity (cell line cultures)}

For MTT (3-[4,5-methylthiazol-2-yl]-2,5-diphenyl-tetrazolium bromide) cytotoxicity assay $\left(\mathrm{TC}_{50}\right)$ modified Eagle's medium (DMEM), Madin-Darby canine kidney (MDCK) cells by using the 3-(4,5-dimethylthiazol-2-yl)-2,5-diphenyltetrazolium bromide. For the determination of antiviral activity of different algal extracts, it was tested in vitro against $\mathrm{A} / \mathrm{CHICKEN} / \mathrm{M} 7217 \mathrm{~B} / 1 / 2013\left(\mathrm{H}_{5} \mathrm{~N}_{1}\right)$ virus by plaque reduction assay and virus was diluted to give $10^{4} \mathrm{PFU} /$ well. The cell lines were obtained and propagated in Virology Laboratory, National Research Center (NRC), Giza, Egypt.

\subsection{Methods}

\subsubsection{Modification of the chemical composition of the culture medium}

Studying the effect of varying nutritive elements provided by the culture medium (BG-11 0 ), increasing or decreasing of certain element concentration was performed (as single-element stress). Nitrogen and sulfur concentrations used were $0 \mathrm{~g} / 1,1.5 \mathrm{~g} / 1,3 \mathrm{~g} / 1,6 \mathrm{~g} / \mathrm{l}$, and $12 \mathrm{~g} / \mathrm{l}$ for nitrogen and $0 \mathrm{~g} / 1,0.07 \mathrm{~g} / 1,0.15 \mathrm{~g} / 1,0.3 \mathrm{~g} / \mathrm{l}$, and $0.6 \mathrm{~g} / 1$ for sulfur, respectively.

A combination of the two major nutrients used was at a concentration of $6 \mathrm{~g} / 1$ for nitrogen and $0.3 \mathrm{~g} / \mathrm{l}$ for sulfur (as double-element stress).

\subsubsection{Determination of algal growth rates}

Growth of Nostoc linckia culture (free from bacteria) was determined by measuring the optical density at $550 \mathrm{~nm}$ at 5 day intervals though the incubation period of 30 days at the different culture conditions.

\subsubsection{Determination of algal dry weight}

Algal dry biomass was determined at 5-day intervals of the incubation period (using $20 \mathrm{ml}$ algal suspension), filtration, washing, and drying at $105^{\circ} \mathrm{C}$ for $24 \mathrm{~h}$ according to the method described by Talukdar [26].

\subsubsection{Extraction and determination of water-soluble pigments (phycobiliproteins)}

The quantification of total phycobiliproteins was made spectrophotometrically and expressed in $\mathrm{mg} / \mathrm{g}$ dry cell weight basis using the following equations [27].

$$
\begin{aligned}
& \text { Phycocyanin }(\mathrm{PC})=\left(A_{615}-\left(0.474 \times A_{652}\right)\right) / 5.34 \\
& \text { Allophycocyanin }(\mathrm{APC})=\left(A_{652}-\left(0.208 \times A_{615}\right)\right) / 5.09
\end{aligned}
$$


Phycoerythrin $(\mathrm{PE})=\left(A_{562}-(2.41 \times \mathrm{PC})-(0.849 \times \mathrm{APC})\right) / 9.62$

Total phycobiliproteins $=\mathrm{PC}+\mathrm{PE}+\mathrm{APC}$

where $A_{615}, A_{652}$, and $A_{562}$ were the absorbance at $615 \mathrm{~nm}$, $652 \mathrm{~nm}$, and $562 \mathrm{~nm}$, respectively. The crude extract was prepared by suspending the biomass in potassium phosphate buffer of $\mathrm{pH} 7$ and ultrasonic cell disruption, followed by the clarification of the extract by high-speed centrifugation.

\subsubsection{Extraction of algal biomass}

The dried algal biomass was extracted three times with an organic solvent mixture of methanol and methylene chloride (1:1) for $40 \mathrm{~min}$, followed by centrifugation, filtration, and evaporation of solvents using a rotary evaporator at 40-50 ${ }^{\circ} \mathrm{C}$. The obtained crude extract was expressed as a percentage of the dried biomass weight used (mg extract/g dry biomass weight).

\subsubsection{Determination of total phenolic contents}

Phenolic contents in the crude extract was determined according to the method of Taga et al. [28] and expressed as gallic acid equivalent/gram (GAE/g) of the alga.

\subsubsection{Determination of flavonoid contents}

Flavonoid content in the algal extract was determined by the spectrophotometric method recorded by Quettier et al. [29] and expressed in terms of rutin equivalent $(\mathrm{mg}$ of $\mathrm{Ru} / \mathrm{g}$ of extract)

\subsubsection{Determination of tannins}

Using vanillin hydrochloride method of Broadhurst and Jones [30], the amount of tannic acid in the sample was recorded from the standard curve and expressed as tannic equivalents.

\subsubsection{Total protein determination}

Extraction of protein was performed according the modified method of Rausch [31] and total protein concentration was determined using the method of Lowry et al. [32], and absorbance was recorded at $720 \mathrm{~nm}$. Total protein was determined using the calibration curve of BSA.

\subsubsection{Determination of antioxidant enzymes and lipid peroxidation}

1. Catalase estimation

Algal homogenate + phosphate buffer $+\mathrm{H}_{2} \mathrm{O}_{2}$ at $25^{\circ} \mathrm{C}$ was incubated for $1 \mathrm{~min}$. Then, after incubation of chromogen inhibitor and enzyme peroxidase and preservative for $10 \mathrm{~min}$ at $37^{\circ} \mathrm{C}$, the absorbance of the sample against sample blank and the standard against standard blank was recorded using methods of [33]) and Fossati et al. [34] and the catalase activity was calculated as $\mathrm{U} / \mathrm{g}=A_{\text {standard }}-A_{\text {sample }} / A_{\text {standard }} \times 1 / \mathrm{g}$ biomass used.

\section{Glutathione $S$-transferase}

Algal homogenate and phosphate buffer at $\mathrm{pH} 7.4+$ reduced glutathione (GSH) was incubated at $37^{\circ} \mathrm{C}$ for $5 \mathrm{~min}$. Then, CDNB was added and incubated at $37^{\circ} \mathrm{C}$ for $5 \mathrm{~min}$ and finally mixed with TCA and centrifuged at $3000 \mathrm{rpm}$ for 5 min. The absorbance of the sample $\left(A_{\text {sample }}\right)$ against blank at $340 \mathrm{~nm}$ was recorded, and the activity was calculated as $\mathrm{U} / \mathrm{g}$ biomass $=A_{\text {sample }} \times 2.812 / \mathrm{g}$ biomass sample according to the method reported by Habig et al. [35].

\section{Lipid peroxidation (MDA determination method)}

Algal homogenate + phosphate buffer ( $\mathrm{pH} 7.5)$ was centrifuged at $4000 \mathrm{rpm}$ for $15 \mathrm{~min}$. Supernatant + chromogen was heated in boiling water bath for $30 \mathrm{~min}$ and allowed to cool, and the absorbance of the algal sample $\left(A_{\text {sample }}\right)$ against blank and the standard against distilled water was determined to be at $354 \mathrm{~nm}$.

MDA in algal sample (nmol/g algal biomass) $=A_{\text {sample }} /$ $A_{\text {standard }} \times 10 / \mathrm{g}$ tissue used. According the method described by Ohkawa et al. [36].

\subsubsection{Biological activities of algal extract}

For determination of biological activities of the crude extract produced from Nostoc linckia cultured in BG-11 0 growth medium (control) and altered (stressed) medium BG-11 0 with modified contents of nitrogen and sulfur, single or in combination, the following activities were performed:

\section{A. Antioxidant activity}

\section{DPPH radical scavenging activity}

The scavenging effects of crude methanol:methylene chloride $(1: 1)$ extract were determined by the method of Yen and Chen [37], where $2.0 \mathrm{ml}$ of $0.16 \mathrm{mM}$ DPPH solution (in methanol) was added to a test tube containing a $2.0-\mathrm{ml}$ aliquot of the sample. The mixture was vortexed for $1 \mathrm{~min}$ and kept at room temperature for $30 \mathrm{~min}$ in the dark. The absorbance of all the sample solutions and BHT as synthetic standard were measured at $517 \mathrm{~nm}$. The percentage (\%) of scavenging activity was calculated as follows:

$\%$ Antioxidant activity $=($ Control - Sample $\times 100) /$ Control 
where control in DPPH solution is $0.16 \mathrm{mM}$.

\section{ABTS radical cation scavenging assay}

This assay was based on the ability of different substances to scavenge $\mathrm{ABTS}^{+}$radical cation in comparison to a standard (BHT). The radical cation was prepared by mixing $7 \mathrm{mM}$ ABTS stock solution with $2.45 \mathrm{mM}$ potassium persulfate $(1 / 1, \mathrm{v} / \mathrm{v})$ and leaving the mixture for $4-16 \mathrm{~h}$ until the reaction was completed and the absorbance was stable. The ABTS ${ }^{+}$ solution was diluted with ethanol to an absorbance of $0.700 \pm$ 0.05 at $734 \mathrm{~nm}$ for measurements according to Re et al. [38]. The photometric assay was conducted on $0.9 \mathrm{ml}$ of ABTS ${ }^{+}$ and $0.1 \mathrm{ml}$ of tested samples and mixed for $45 \mathrm{~s}$, and measurements were taken at $734 \mathrm{~nm}$ after $1 \mathrm{~min}$. The antioxidant activity of the tested samples was calculated by determining the decrease in absorbance at different concentrations by using the following equation: $E=\left(\left(A_{\mathrm{c}}-A_{\mathrm{t}}\right) / A_{\mathrm{c}}\right) \times 100$, where $A_{\mathrm{t}}$ and $A_{\mathrm{c}}$ are the absorbance of tested samples and $\mathrm{ABTS}^{+}$, respectively.

\section{B. Anticancer activity}

\section{Evaluation of cell proliferation by MTT assay}

The cytotoxic effect of the crude extracts and fractions of Nostoc linckia on different cancer cell lines was evaluated by the MTT assay as reported previously with slight modification [39]. In brief, after evaluation of cell count and viability by Trypan blue dye, cancer cells $\left(1 \times 10^{4}\right.$ cells/well $)$ were seeded in a 96-well plate in triplicate and were allowed to adhere for $24 \mathrm{~h}$.

The crude extracts were weighted and dissolved in $1 \mathrm{ml}$ dimethylsulfoxide (DMSO) to have a stock solution of 2000 $\mu \mathrm{g} / \mathrm{ml}$, as the final concentration of DMSO in the culture medium never exceeded $0.2 \%(\mathrm{v} / \mathrm{v})$ [40] and then various concentrations of crude extracts were prepared by further diluting in complete medium to have a final concentration of $31.5 \mu \mathrm{g} / \mathrm{ml}, 62.5 \mu \mathrm{g} / \mathrm{ml}, 125 \mu \mathrm{g} / \mathrm{ml}, 250 \mu \mathrm{g} / \mathrm{ml}$, and 500 $\mu \mathrm{g} / \mathrm{ml}$. In the next day, the medium was replaced with fresh medium with the indicated concentrations of tested compounds and cells were allowed to grow for $48 \mathrm{~h}$. Four hours before completion of incubation, $10 \mu \mathrm{l}$ of MTT $(5 \mathrm{mg} / \mathrm{ml}$ in phosphate-buffered saline (PBS) w/o Ca and Mg; Lonza Verviers SPRL, Belgium, cat\# 17-516F) was added in each well. After completing the incubation, $100 \mu \mathrm{l}$ of DMSO was added to each well, and then the 96-well plates were centrifuged for $5 \mathrm{~min}$ at $4000 \mathrm{rpm}$ to precipitate the formazan crystals. Color developed after the reaction was measured at $490 \mathrm{~nm}$ using a BioTek microplate reader.

The experiment was conducted in triplicate, and data were calculated as percent of cell viability by the following formula: \% Cell viability $=($ Mean absorbance in test wells $/$ Mean absorbance in control wells) $\times 100$.

\section{Antimicrobial assay}

To investigate the antimicrobial activity of secondary metabolites produced under normal and stressed culture conditions of the selected alga for this study (Nostoc linckia), the agar well diffusion method [41] was used. Algal extracts were tested in vitro for their antibacterial activity against Staphylococcus aureus and Streptococcus mutans (Gram-positive bacteria), Escherichia coli and Klebsiella pneumoniae (Gram-negative bacteria) using the Luria-Bertani agar medium [42], and fungal strains (Aspergillus niger and Candida albicans) cultured and maintained on the Sabouraud dextrose medium [43]. Ampicillin $(10 \mu \mathrm{g})$ and gentamicin $(120 \mu \mathrm{g})$ were used as standard drugs for Gram-positive and Gramnegative bacteria, respectively, while nystatin (100 units) was used as standard antifungal activity agent (positive control) and DMSO was used as negative control. The extracts were tested at a concentration of $1.5 \mathrm{mg} / \mathrm{ml}$ against both bacterial strains. The activity was expressed as the diameter of inhibition zones in $\mathrm{mm}$.

\section{Antiviral activity}

\section{MTT cytotoxicity assay $\left(\mathrm{TC}_{50}\right)$}

Samples were diluted with DMEM. Stock solutions of the algal extracts were prepared in $10 \%$ DMSO in doubledistilled $\mathrm{H}_{2} \mathrm{O}$. The cytotoxic activity of the extracts was tested in MDCK cells by using the MTT method [44] with minor modification. Briefly, the cells were seeded in 96-well plates $\left(100 \mu \mathrm{l} /\right.$ well at a density of $\left.3 \times 10^{5} \mathrm{cells} / \mathrm{ml}\right)$ and incubated for $24 \mathrm{~h}$ at $37{ }^{\circ} \mathrm{C}$ in $5 \% \mathrm{CO}_{2}$. After $24 \mathrm{~h}$, cells were treated with various concentrations of the tested extracts in triplicates. After further $24 \mathrm{~h}$, the supernatant was discarded and cell monolayers were washed with sterile PBS 3 times and MTT solution ( $20 \mu \mathrm{l}$ of $5 \mathrm{mg} / \mathrm{ml}$ stock solution) was added to each well and incubated at $37^{\circ} \mathrm{C}$ for $4 \mathrm{~h}$, followed by medium aspiration. In each well, the formed formazan crystals were dissolved with $200 \mu$ l of acidified isopropanol $(0.04 \mathrm{M} \mathrm{HCl}$ in absolute isopropanol $=0.073 \mathrm{ml} \mathrm{HCl}$ in $50 \mathrm{ml}$ isopropanol). Absorbance of formazan solutions was measured at $\lambda_{\max } 540 \mathrm{~nm}$ with $620 \mathrm{~nm}$ as a reference wavelength using a multiwell plate reader. The percentage of cytotoxicity compared to the untreated cells was determined with the following equation. The plot of $\%$ cytotoxicity versus sample concentration was used to calculate the concentration which exhibited $50 \%$ cytotoxicity $\left(\mathrm{TC}_{50}\right)$.

$\%$ Cytotoxicity $=($ Absorbance of cells without treatment Absorbance of cells with treatment $) \times 100 /$ Absorbance of cells without treatment 


\section{Plaque reduction assay}

Assay was carried out according to the method of Hayden et al. [45] in a six-well plate where MDCK cells $\left(10^{5}\right.$ cells $\left./ \mathrm{ml}\right)$ were cultivated for $24 \mathrm{~h}$ at $37{ }^{\circ} \mathrm{C}$. A/CHICKEN/M7217B/1/ $2013\left(\mathrm{H}_{5} \mathrm{~N}_{1}\right)$ virus was diluted to give $10^{4} \mathrm{PFU} /$ well, mixed with the safe concentration of the algal extracts, and incubated for $1 \mathrm{~h}$ at $37{ }^{\circ} \mathrm{C}$ before being added to the cells. Growth medium was removed from the cell culture plates, and the cells were inoculated with $100 \mu \mathrm{l} /$ well virus with the tested extracts, After $1 \mathrm{~h}$ of contact time for virus adsorption, $3 \mathrm{ml}$ of DMEM supplemented with $2 \%$ agarose and the tested extracts was added onto the cell monolayer, and plates were left to solidify and incubated at $37{ }^{\circ} \mathrm{C}$ till formation of viral plaques ( 3 to 4 days). Formalin (10\%) was added for $2 \mathrm{~h}$, then plates were stained with $0.1 \%$ crystal violet in distilled water. Control wells were included where untreated virus was incubated with MDCK cells, and finally, plaques were counted and percentage reduction in plaque formation in comparison to control wells was recorded as follows:

$\%$ Inhibition $=$ Viral count $($ untreated $)-$ Viral count (treated) / Viral count (untreated) $\times 100$

\subsubsection{GC-MS analysis}

The chemical composition was determined using a Trace GC1300-TSQ mass spectrometer (Thermo Scientific, Austin, TX, USA) with a direct capillary column (TG-5MS, $30 \mathrm{~m} \times 0.25 \mathrm{~mm} \times 0.25 \mu \mathrm{m}$ film thickness). The column oven temperature was initially held at $60{ }^{\circ} \mathrm{C}$ and then increased by $5{ }^{\circ} \mathrm{C} / \mathrm{min}$ to $200{ }^{\circ} \mathrm{C}$, hold for $2 \mathrm{~min}$, increased to the final temperature of $300{ }^{\circ} \mathrm{C}$ by $20{ }^{\circ} \mathrm{C} / \mathrm{min}$, and hold for $2 \mathrm{~min}$. The injector and MS transfer line temperatures were kept at $250{ }^{\circ} \mathrm{C}$ and $260{ }^{\circ} \mathrm{C}$, respectively. Helium was used as a carrier gas at a constant flow rate of $1 \mathrm{ml} / \mathrm{min}$. The solvent delay was $3 \mathrm{~min}$, and diluted samples of $1 \mu \mathrm{l}$ were injected automatically using an AS1300 autosampler coupled with GC in the split mode. EI mass spectra were collected at $70 \mathrm{eV}$ ionization voltages over the range of $\mathrm{m} / \mathrm{z} 50-650$ in full scan mode. The ion source temperature was set at $250{ }^{\circ} \mathrm{C}$. The components were identified by comparison of their retention times and mass spectra with those of Wiley 09 and NIST 11 mass spectral database.

\subsubsection{Statistical analysis}

All the data are expressed as mean \pm standard deviation of three determinations. Statistical comparison was performed via a one-way analysis of variance followed by Duncan's multiple range test (DMRT). $P$ values of less than $0.05(P<$ $0.05)$ were considered as significant.

\section{Results and discussion}

\subsection{Effect of culture media composition (nitrogen and sulfur) on the growth of Nostoc linckia}

The data in Fig. 1 shows the effect of different nitrogen concentrations ( $0.0 \mathrm{~g} / 1,1.5 \mathrm{~g} / \mathrm{l}, 3 \mathrm{~g} / 1,6 \mathrm{~g} / 1$, and $12 \mathrm{~g} / \mathrm{l}$ nitrogen), sulfur concentrations $(0.0 \mathrm{~g} / 1,0.07 \mathrm{~g} / 1,0.15 \mathrm{~g} / 1,0.3 \mathrm{~g} / 1$, and 0.6 $\mathrm{g} / \mathrm{l}$ sulfur), and a combination between $0.3 \mathrm{~g} / \mathrm{l}$ sulfur and $6 \mathrm{~g} / \mathrm{l}$ nitrogen on the growth of $N$. linckia during the cultivation period of 30 days on BG- $11_{0}$ medium. The results presented in Fig. 1a and b show a significant increment of growth (OD and dry weight (DW)) with elevation of nitrogen concentration and time of incubation especially at $1.5 \mathrm{~g} / \mathrm{l}$ and $3 \mathrm{~g} / \mathrm{l}$ nitrogen concentrations, while higher doses of nitrogen of 6 $\mathrm{g} / 1$ and $12 \mathrm{~g} / \mathrm{l}$ induced significantly marked retardation of growth during all the cultivation periods. Maximum growth rate of $N$. linckia was achieved by $3 \mathrm{~g} / 1$ nitrate at the 25 th day of cultivation $(0.83 \pm 0.008$ and $0.88 \pm 0.009$ representing DW and OD, respectively) as nitrogen availability in optimum concentration is involved in different vital processes and metabolic pathways. Also, nitrogen is one of the most important elements for algal growth as it is a key constituent of amino acids, proteins, RNA, and DNA in all algal species.

In contrast, elevated nitrogen concentration $(6 \mathrm{~g} / 1$ and 12 $\mathrm{g} / \mathrm{l}$ ) induced an obvious, gradual and significant retardation in growth parameters during the incubation periods and alga stopped completely to grow on day 15 of cultivation. These inhibitory effects of higher nitrogen concentrations were due to its toxic influence to all vital processes and led to death of the alga.

This alga like all the heterocystous cyanobacteria is able to fix atmospheric nitrogen to satisfy its requirements of nitrogenous substances to grow and undergo primary and secondary metabolism.

Also, nitrogen fixation takes place by the activity of metalloprotein complex (known as nitrogenase enzyme) cofactor by seven metals (Fe, Mo, Ni, Mn, V, Cu, and $\mathrm{Zn}$ ) and occurred in the absence of $\mathrm{O}_{2}$ (or in microaerobic conditions) in the dark or even in the light. The addition of nitrogen source in the culture media of this alga induces inhibition of nitrogenase enzyme synthesis.

These results were in agreement with the results obtained by Solovchenko et al. [46]; Koksharova et al. [47] indicated that algal biomass productivity and its photochemical efficiency in addition to proteins and DNA repair enzymes are directly proportional to the nitrogen concentration.

The effect of sulfur concentration on the growth rate of $N$. linckia and sulfur concentrations $(0.00 \mathrm{~g} / 1,0.075 \mathrm{~g} / \mathrm{l}, 0.15$ $\mathrm{g} / 1,0.3 \mathrm{~g} / 1$, and $0.6 \mathrm{~g} / \mathrm{l}$ ) were investigated. The data present in Fig. 1c and d show that, at $0.0 \mathrm{~g} / 1$ sulfur (starvation), algal growth was slow, reached its maximum on the 15th day of cultivation, then started to decrease and stop completely after 

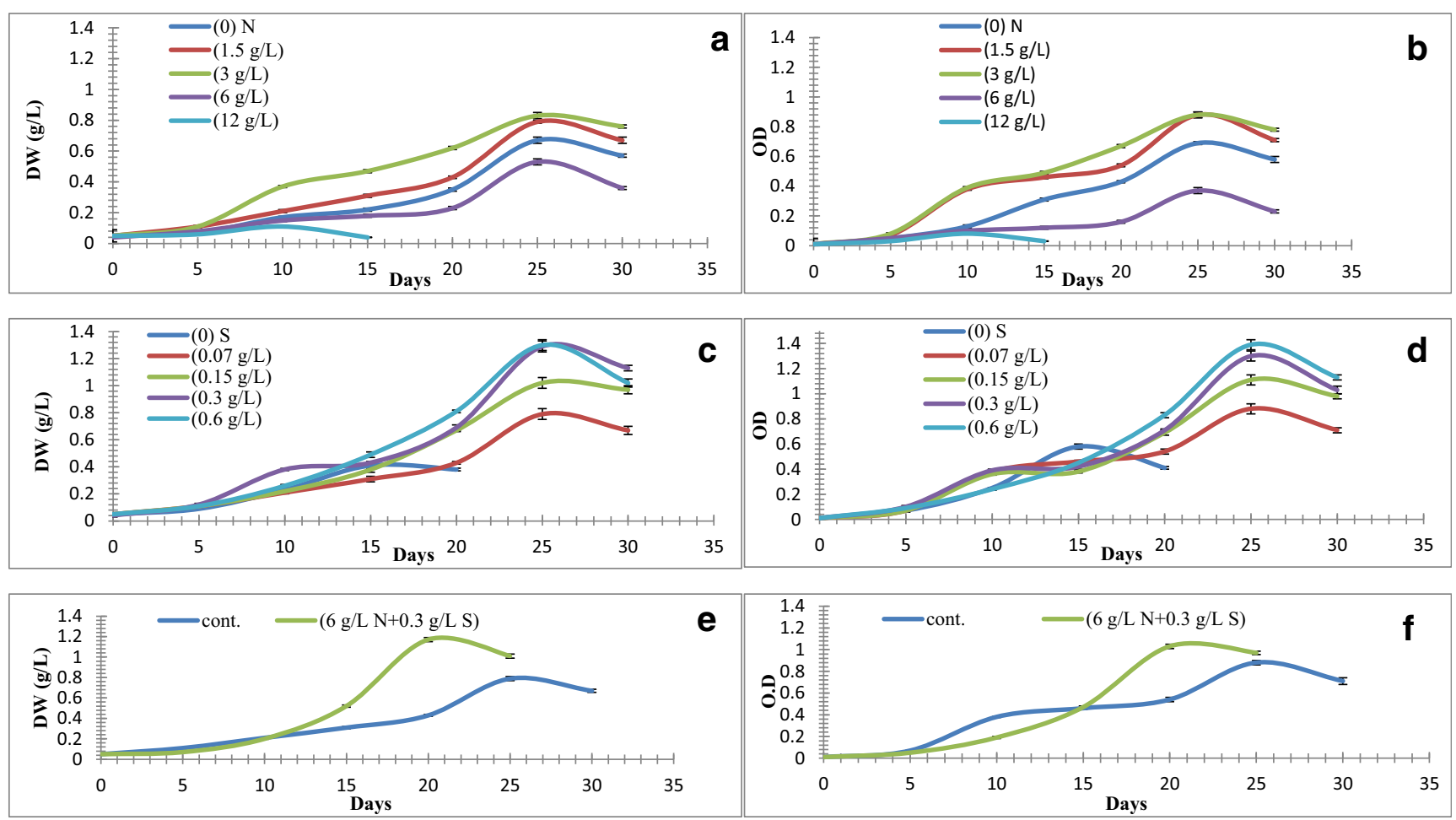

Fig. 1 a-f Growth curves of $N$. linckia (DW (g/l) and OD) during 30 days of cultivation under different nitrogen and sulfur concentrations and their combination

the 20th day of incubation. The obtained results coincided with the results reported by Zalutskaya et al. [48] on Chlamydomonas reinhardtii, where any stimulus (as sulfur starvation) causes the cytochrome-pathway complex dysfunction in mitochondrial electron transport chains, which led to the induction and expression of alternative oxidase 1 and 2 genes. Moreover, under sulfur starvation condition, photosynthetic activity and metabolism are affected [49].

On the contrary, increasing sulfur concentration led to an enhancement of algal growth in a time-dependent manner. Increasing sulfur concentrations $(0.075-0.6 \mathrm{~g} / \mathrm{l})$ induced significant enhancement in growth parameters (DW and OD) recording $1.030 \pm 0.005$ and $1.39 \pm 0.100$, respectively, at the 25 th day of cultivation of $N$. linckia at $0.6 \mathrm{~g} / \mathrm{l}$. Sulfur is one of the most essential macronutrients used for growth and survival of algae. It is included in the synthesis of biomolecules; iron-sulfur-proteins (as ferredoxin), as cofactors in enzymes; and vitamins as thiamine, biotin, and thiouridine, in various amino acids (as cysteine and methionine) and in sulfur-containing secondary metabolites [48].

The effect of combined $\mathrm{N}$ and $\mathrm{S}$ at concentrations of $6 \mathrm{~g} / \mathrm{l}$ and $0.3 \mathrm{~g} / \mathrm{l}$, respectively, recorded in Fig. 1e and f illustrated that there was a significant and obvious enhancement of growth compared to that of the normal medium (1.17 \pm 0.069 and $1.03 \pm 0.060$ of DW and OD, respectively) at the 20th day of growth, after which a relatively slight decrease in growth was observed at the combined $\mathrm{N}$ and $\mathrm{S}$ concentrations which is still higher than that obtained by the control at the 25 th day of growth.

These findings were in agreement with Balaguer et al. [50], who studied the interactive effect of $\mathrm{SO}_{2}$ and $\mathrm{NO}_{3}$ on the growth of the green algal lichen Ramalina farinacea. They found that there was a synergistic effect in case of a combination between the two elements, leading to an increase in growth when compared to the effect of each element separately. As the dose increased, antagonistic effects were developed.

\subsection{Pigment contents (phycobiliproteins) of $N$. linckia under different $\mathbf{N}$ and $\mathbf{S}$ stress conditions}

Increasing $\mathrm{N}$ concentration from 0.0 to $1.5 \mathrm{~g} / \mathrm{l}$ and $3 \mathrm{~g} / \mathrm{l}$ led to a significant and pronounced increase in all phycobiliprotein pigments which reached its maximum values at $3 \mathrm{~g} / 1$ ( 76.28 $\pm 4.61,37.19 \pm 2.44$, and $146.82 \pm 4.11$ in phycocyanin, allophycocyanin, and phycoerythrin, respectively), as recorded in Table 1.

In cyanobacteria, the phycobiliproteins constitute major light-harvesting pigments, which are attached to the outer surface of the thylakoid membrane in an aggregated complex called the phycobilisomes [51]. Various environmental factors are known to affect the efficiency of energy transfer from PBSs to chlorophyll [52].

Phycobiliproteins serve as a nitrogen storage compound. They mobilize their intracellular nitrogen storage constituents 
Table 1 Phycobiliprotein pigment contents as $\mu \mathrm{g} / \mathrm{g}$ for $N$. linckia cultivated under different concentrations of nitrogen and sulfur

\begin{tabular}{lllll}
\hline Stress conditions & Phycocyanin & Allophycocyanin & Phycoerythrin & Total phycobiliprotein \\
\hline Nitrogen $(\mathrm{g} / \mathrm{l})$ & & & & \\
0 & $60.64 \pm 3.42^{\mathrm{b}}$ & $17.80 \pm 2.15^{\mathrm{c}}$ & $123.05 \pm 4.59^{\mathrm{b}}$ & $200.49 \pm 5.361^{\mathrm{b}}$ \\
1.5 & $90.32 \pm 2.41^{\mathrm{c}}$ & $18.61 \pm 2.14^{\mathrm{c}}$ & $123.05 \pm 0.52^{\mathrm{d}}$ & $211.98 \pm 4.71^{\mathrm{d}}$ \\
3 & $76.28 \pm 4.61^{\mathrm{a}}$ & $37.19 \pm 2.44^{\mathrm{a}}$ & $146.82 \pm 4.11^{\mathrm{a}}$ & $276.29 \pm 5.45^{\mathrm{a}}$ \\
6 & $27.36 \pm 2.52^{\mathrm{d}}$ & $15.61 \pm 1.09^{\mathrm{d}}$ & $35.66 \pm 2.12^{\mathrm{e}}$ & $78.63 \pm 3.14^{\mathrm{e}}$ \\
12 & $7.63 \pm 1.03^{\mathrm{e}}$ & $4.09 \pm 1.05^{\mathrm{e}}$ & $10.09 \pm 0.002^{\mathrm{f}}$ & $21.83 \pm 2.02^{\mathrm{f}}$ \\
$6 \mathrm{~g} / 1\left(\mathrm{NaNO}_{3}\right)+0.3 \mathrm{~g} / 1\left(\mathrm{MgSO}_{4} \cdot 7 \mathrm{H}_{2} \mathrm{O}\right)$ & $67.37 \pm 3.47^{\mathrm{b}}$ & $22.50 \pm 2.40^{\mathrm{b}}$ & $88.01 \pm 4.49^{\mathrm{c}}$ & $177.88 \pm 7.48^{\mathrm{c}}$ \\
$\mathrm{Sulfur}(\mathrm{g} / \mathrm{l})$ & & & $16.39 \pm 1.32^{\mathrm{f}}$ & $39.25 \pm 2.40^{\mathrm{e}}$ \\
0 & $14.52 \pm 1.05^{\mathrm{d}}$ & $9.341 \pm 1.04^{\mathrm{e}}$ & $123.05 \pm 4.59^{\mathrm{a}}$ & $200.49 \pm 5.36^{\mathrm{c}}$ \\
0.07 & $60.64 \pm 3.42^{\mathrm{c}}$ & $17.80 \pm 2.15^{\mathrm{f}}$ & $102.30 \pm 3.37^{\mathrm{d}}$ & $199.20 \pm 6.39^{\mathrm{c}}$ \\
0.15 & $66.47 \pm 3.46^{\mathrm{b}}$ & $30.43 \pm 2.39^{\mathrm{c}}$ & $105.62 \pm 4.35^{\mathrm{c}}$ & $209.27 \pm 7.36^{\mathrm{b}}$ \\
0.3 & $62.37 \pm 3.43^{\mathrm{c}}$ & $41.28 \pm 2.48^{\mathrm{b}}$ & $113.95 \pm 4.33^{\mathrm{b}}$ & $239.74 \pm 7.18^{\mathrm{a}}$ \\
0.6 & $71.60 \pm 3.26^{\mathrm{a}}$ & $54.19 \pm 3.53^{\mathrm{a}}$ & $88.01 \pm 4.49^{\mathrm{e}}$ & $177.88 \pm 7.48^{\mathrm{d}}$ \\
$6 \mathrm{~g} / 1\left(\mathrm{NaNO}_{3}\right)+0.3 \mathrm{~g} / 1\left(\mathrm{MgSO}_{4} \cdot 7 \mathrm{H}_{2} \mathrm{O}\right)$ & $67.37 \pm 3.47^{\mathrm{b}}$ & $22.50 \pm 2.40^{\mathrm{d}}$ & & \\
\hline
\end{tabular}

Data are presented as means $\pm \mathrm{SD}(n=3)$ in each column, and for each concentration, means with different letters are significantly different $(p<0.05)$

for other cellular activities during nitrogen shortage. Combined $6 \mathrm{~g} / 1 \mathrm{~N}$ and $0.3 \mathrm{~g} / \mathrm{l} \mathrm{S}$ was shown to inhibit the production of all phycobiliprotein pigments $(67.37 \pm 3.47$ for phycocyanin, $22.50 \pm 2.40$ for allophycocyanin, and $88.01 \pm 4.49$ for phycoerythrin; total phycobiliprotein content $276.29 \pm 5.45)$.

Our results were in agreement with Shanab et al. [12], who found that Nostoc muscorum and Oscillatoria sp. can be cultured under nitrogen stress conditions (by both increasing and decreasing the nitrate content of the normal BG-11 medium, $1.5 \mathrm{~g} / \mathrm{l})$. They found that, by increasing nitrate concentration $(3 \mathrm{~g} / \mathrm{l}, 6 \mathrm{~g} / \mathrm{l}$, and $9 \mathrm{~g} / \mathrm{l})$, a remarkable increase in phycobilin pigments was observed, followed by an increase in antioxidant and anticancer activities of both studied cyanobacterial species.

Johnson et al. [53] and Nayak et al. [54] proved that in Nostoc sp. (nitrogen-fixing cyanobacteria), supplementation of external nitrogen source in the form of sodium nitrate was found to increase the total phycobiliprotein content by fivefold. The most suitable concentration of sodium nitrate was $17.65 \mathrm{mM}$, yielding a total phycobiliprotein content of $0.10 \mathrm{~g} /$ $\mathrm{g}$ of dry cell weight compared to a control. Synthesis of phycobiliproteins was reduced at higher concentration of sodium nitrate. This may be because of substrate inhibition experienced by the cells.

More elevated nitrogen concentrations $(6 \mathrm{~g} / \mathrm{l}$ and $12 \mathrm{~g} / \mathrm{l})$ were found to be inhibitory. These results coincided with those of Loaiza et al. [55], who proved that synthesis of pigments, especially phycobiliproteins, is particularly susceptible to environmental influences. For Nostoc, nitrogen-limited cultures actually produce more phycobiliproteins than nonlimited cultures. This can be explained through nitrogen fixation. Heterocystous cyanobacteria, such as Nostoc and Anabaena, are capable to fix the atmospheric nitrogen, to produce chlorophyll, carotenoids, and phycobiliproteins in significant quantities, and that can be seen in the results, especially with Nostoc strains.

On the contrary, elevated sulfur concentration $(0.6 \mathrm{~g} / \mathrm{l})$ induced a significant enhancement in all pigments $(71.60 \pm 3.26$ in case of phycocyanin, $54.19 \pm 3.53$ in allophycocyanin, and $113.95 \pm 4.33$ in phycoerythrin with a total phycobiliprotein content reaching $239.74 \pm 7.18$, an increment of phycobiliprotein as shown in Table 1).

Increasing sulfur concentration may be related to that pigmentation of light-harvesting phycobiliproteins of cyanobacteria may require covalent attachment of openchain tetrapyrroles and bilins to the apoproteins. Formation of thioether bond via the addition of a cysteine residue to the 3 -ethylidene substituent of bilins is interceded by lyases. Ttype lyases are responsible for attachment to Cys-155 of phycobiliprotein $\beta$ subunits $[56,57]$.

\subsection{Effect of culture media composition on secondary metabolite production of $N$. linckia}

Table 2 shows that nitrogen depletion provoked significantly highest quantities of phenolic content $(27.00 \pm 1.0)$, flavonoids $(21.14 \pm 0.80)$, and tannins $(6.54 \pm 0.43)$, which were in a good agreement with $\mathrm{Li}$ et al. [58], who proved that total phenolics were inversely proportional to nitrogen supply in two genotypes of leaf mustard (cvs. 'Xuelihong' and 'Zhujie'). Also, these results were in parallel with those reported by Al-Rashed et al. [59], who found that both phenolic and flavonoid contents increased significantly under nitrogen 
Table 2 Phenolic, flavonoid, tannin, and proline contents of $N$. linckia cultivated under different concentrations of nitrogen and sulfur (and combined nitrogen and sulfur)

\begin{tabular}{|c|c|c|c|c|}
\hline Stress conditions & $\begin{array}{l}\text { Phenolic contents (mg gallic } \\
\text { acid equivalent/g DW) }\end{array}$ & $\begin{array}{l}\text { Flavonoids (mg of } \\
\text { rutin } / \mathrm{g} \text { DW) }\end{array}$ & $\begin{array}{l}\text { Tannins (mg tannic acid } \\
\text { equivalent/g DW) }\end{array}$ & Proline contents $(\mathrm{mg} / \mathrm{g})$ \\
\hline \multicolumn{5}{|l|}{ Nitrogen $(g / 1)$} \\
\hline 0 & $27.00 \pm 1.0^{\mathrm{b}}$ & $21.14 \pm 0.80^{\mathrm{a}}$ & $6.54 \pm 0.43^{\mathrm{a}}$ & $4.77 \pm 0.47^{\mathrm{cd}}$ \\
\hline 1.5 & $24.25 \pm 1.39 b^{c}$ & $18.13 \pm 1.02^{\mathrm{b}}$ & $5.45 \pm 0.47^{\mathrm{b}}$ & $3.56 \pm 0.40^{\mathrm{d}}$ \\
\hline 3 & $22.35 \pm 1.46^{\mathrm{c}}$ & $10.26 \pm 0.64^{\mathrm{c}}$ & $2.17 \pm 0.29^{\mathrm{d}}$ & $5.06 \pm 0.30^{\mathrm{bc}}$ \\
\hline 6 & $17.90 \pm 1.15^{\mathrm{d}}$ & $6.10 \pm 0.85^{\mathrm{d}}$ & $2.39 \pm 0.44^{\mathrm{cd}}$ & $6.23 \pm 0.58^{\mathrm{b}}$ \\
\hline 12 & $13.00 \pm 1.9^{\mathrm{e}}$ & $9.30 \pm 1.08^{\mathrm{c}}$ & $1.73 \pm 0.11^{\mathrm{d}}$ & $10.92 \pm 0.61^{\mathrm{a}}$ \\
\hline $6 \mathrm{~g} / 1 \mathrm{~N}+0.3 \mathrm{~g} / 1 \mathrm{~S}$ & $41.00 \pm 1.0^{\mathrm{a}}$ & $2.90 \pm 0.65^{\mathrm{e}}$ & $3.19 \pm 0.35^{\mathrm{c}}$ & $4.43 \pm 0.51^{\mathrm{cd}}$ \\
\hline \multicolumn{5}{|l|}{ Sulfur $(g / 1)$} \\
\hline 0 & $34.74 \pm 0.63^{\mathrm{c}}$ & $15.90 \pm 0.39^{\mathrm{b}}$ & $1.81 \pm 0.51^{\mathrm{f}}$ & $12.15 \pm 0.58^{\mathrm{a}}$ \\
\hline 0.07 & $24.25 \pm 1.39^{\mathrm{d}}$ & $18.13 \pm 1.03^{\mathrm{a}}$ & $5.45 \pm 0.47^{\mathrm{d}}$ & $3.57 \pm 0.40^{\mathrm{bc}}$ \\
\hline 0.15 & $44.94 \pm 0.96^{\mathrm{a}}$ & $14.56 \pm 0.51^{\mathrm{b}}$ & $8.53 \pm 0.41^{\mathrm{c}}$ & $4.52 \pm 0.47^{\mathrm{b}}$ \\
\hline 0.3 & $47.32 \pm 0.58^{\mathrm{a}}$ & $10.91 \pm 0.72^{\mathrm{c}}$ & $13.77 \pm 0.58^{\mathrm{b}}$ & $2.95 \pm 0.18^{\mathrm{c}}$ \\
\hline 0.6 & $25.00 \pm 1.00^{\mathrm{d}}$ & $15.22 \pm 0.59^{\mathrm{b}}$ & $19.00 \pm 0.99^{\mathrm{a}}$ & $3.50 \pm 0.50^{\mathrm{bc}}$ \\
\hline $6 \mathrm{~g} / 1 \mathrm{~N}+0.3 \mathrm{~g} / 1 \mathrm{~S}$ & $41.00 \pm 1.00^{\mathrm{b}}$ & $2.90 \pm 0.65^{\mathrm{e}}$ & $3.19 \pm 0.35^{\mathrm{e}}$ & $4.20 \pm 0.85^{\mathrm{bc}}$ \\
\hline
\end{tabular}

Data are presented as means $\pm \mathrm{SD}(n=3)$ in each column, and for each concentration, means with different letters are significantly different $(p<0.05)$

deprivation on the growth rate of Spirulina platensis and Dunaliella salina.

Short-term nitrogen starvation induced oxidative stress of the green microalga Acutodesmus dimorphus and accumulation of ROS, proline, and polyphenols as well as higher activities of the antioxidant enzymes (catalase, superoxide dismutase, and ascorbate peroxidase) and stress hormone ABA [60].

The obtained results coincided with Hamid and Sibi [61], who proved that the increment of proline contents reached eightfold, and total phenolic contents under nitrogen stress were induced by an antioxidant system in Chlorococcopsis minuta.

Moreover, Allahdadi and Farzane [62] reported that nitrogen application in higher levels improved the growth of artichoke but reduced total phenol, total flavonoid, and antioxidant activity.

However, Lauritano et al. [63] showed that the green alga Tetraselmis suecica was able to activate stress and antioxidant transcripts as well as signaling and solute transporter transcripts, indicating the activation of a series of defense and adaptation strategies to maintain cellular homeostasis and survival.

Secondary metabolites produced by $N$. linckia cultured on different concentrations of sulfur are recorded in Table 2. Maximum proline content $(12.15 \pm 0.58 \mathrm{mg} / \mathrm{g})$ was recorded at $0.0 \mathrm{~g} / 1$ sulfur (S depletion), while significantly great production of flavonoids was achieved at low sulfur concentrations $(0 \mathrm{~g} / 1$ and $0.079 \mathrm{~g} / 1)(15.90 \pm 0.39$ and $18.13 \pm 1.03 \mathrm{mg}$ rutin/g DW).

On the other hand, phenolic contents reached significantly maximum production at $0.15 \mathrm{~g} / 1$ and $0.3 \mathrm{~g} / 1$ sulfur $(44.94 \pm$
0.96 and $47.32 \pm 0.58$, respectively). At high sulfur concentration $(0.6 \mathrm{~g} / \mathrm{l})$, the largest production of tannins (19.00 \pm $0.99 \mathrm{mg}$ tannic acid equivalent/g DW) was recorded. Regarding the combination $\mathrm{N}+\mathrm{S}$, phenolic content was increased twofold than the content produced by $0.3 \mathrm{~g} / \mathrm{l} \mathrm{S}$.

Concerning flavonoids, the combination $\mathrm{N}+\mathrm{S}$ highly decreased the flavonoid production (twofold to threefold decrease) which occurred by the same element concentration separately. In case of tannins, the combination effect slightly increased the quantity produced by $6 \mathrm{~g} / 1 \mathrm{~N}$ but largely decreased the tannin content produced at $0.3 \mathrm{~g} / \mathrm{l} \mathrm{S}$ (fourfold decrease). The proline produced in the combination was lower than that induced at $6 \mathrm{~g} / 1 \mathrm{~N}$ but, at the same time, higher (double) than that at $0.3 \mathrm{~g} / \mathrm{l} \mathrm{S}$.

As sulfur is required for synthesis of important defense compounds as cysteine-rich peptides, phytochelations, metallothioneins as well as reduced GSH are involved in both metal chelation and scavenging of ROS. There was a positive correlation between increasing sulfur concentration and increasing phenolic contents which was in agreement with $\mathrm{Li}$ et al. [58], who determined the effect of sulfur on total phenolics and antioxidant activity in two genotypes of leaf mustard (cvs. 'Xuelihong' and 'Zhujie'). They found that by increasing sulfur concentration $(0.5 \mathrm{mM}, 1 \mathrm{mM}$, and $2 \mathrm{mM})$, total phenolic concentration increased, showing a positive correlation between antioxidant activity (by DPPH method) and total phenolics in the two genotypes. Additionally, Tóth et al. [64] proved that the highest contents of polyphenols were recorded in yellow cultivars. The highest values of antioxidant activity were achieved in all cultivars at the sulfur dose of $40.00 \mathrm{~kg} / \mathrm{ha}$, except for cultivars Boston and Diamant. 


\subsection{Effect of media composition on the production of antioxidant defense enzymes and lipid peroxidation (MDA) of N. linckia}

The highest significant values of lipid peroxidation, enzyme glutathione $S$-transferase, and catalase were recorded at the most elevated nitrogen concentration used (12 g/l) (666.22 \pm $9.07,375.62 \pm 7.35$, and $72.99 \pm 3.00$, respectively), while protein content mostly produced was at $3 \mathrm{~g} / \mathrm{l}$ nitrogen ( 287.30 $\pm 1.30 \mathrm{mg} / \mathrm{g}$ ) as shown in Table 3 .

Mixing $6 \mathrm{~g} / \mathrm{l} \mathrm{N}$ and $0.3 \mathrm{~g} / \mathrm{l} \mathrm{S}$ led to a significant decrease in all the parameters tested compared to their maximum production in the presence of nitrogen concentration only, as obviously seen in Table 3 .

Cells exposed to stresses undergo changes in their metabolism in order to adapt with changes in their environment. Antioxidant enzymes and osmolytes are known to be produced in plants and other organisms in response to stress conditions.

Nitrogen limitation and starvation not only significantly decreased the photosynthetic activity and protein content but also affected the cell morphology of Scenedesmus sp. CCNM1077 as reported by Pancha et al. [65].

Our results were in parallel with those reported by AlRashed et al. [59], who investigated the effect of deprivation of nitrogen stresses on the growth rate of Spirulina platensis and Dunaliella salina, and the increment of some antioxidant compounds, antioxidant enzymes, superoxide dismutase, ascorbate peroxidase, guaiacol peroxidase, and glutathione reductase as well as the levels of total glutathione pool, UVB-absorbing pigments, MDA, and $\mathrm{H}_{2} \mathrm{O}_{2}$ concentrations were studied in Spirulina platensis and Dunaliella salina.
The activities of SOD, CAT, and APX in green microalga Chlorococcopsis minuta were increased under nitrogen stress (deprivation), representing an enhancement in its antioxidant system response [61].

At elevated nitrogen concentrations, in this study, there was an increase in protein contents which may be due to excessive production of stress proteins which agreed with the results obtained by Menegol et al. [66], who found that Heterochlorella luteoviridis biomass production, composition, and protein contents were increased at $138 \mathrm{mg} / \mathrm{g}$, the highest nitrogen concentration $\left(60 \mathrm{mg} / 1 \mathrm{~N}-\mathrm{NO}_{3}\right)$. This value was $45 \%$ higher than that observed in the culture containing the lowest nitrogen concentration $\left(12 \mathrm{mg} / 1 \mathrm{~N}-\mathrm{NO}_{3}\right)$.

Concerning sulfur stress, lipid peroxidation acquired the highest content at sulfur depletion condition $(328.79 \pm 7.90$ MDA nmol/g). Significantly larger contents of protein, GST, and catalase activity were recorded at the highest sulfur concentration used as seen in Table 3.

Sulfur concentrations induced oxidative stress with the generation of a large quantity of ROS which, if not scavenged properly in time, induced damages to biomembranes and biomolecules with elevated lipid peroxidation (MDA), stress protein, and sulfur-containing proteins as well as elevation of the defensive antioxidant enzymes, GST, and catalase.

Glutathione is known to be a crucial sulfur-based molecule for resistance of oxidative stress, and many other intracellular antioxidant mechanisms depend on it and are limited by extracellular sulfur availability [67].

GSTs quench reactive molecules with the conjugation of GSH and detoxify cells from oxidative damage [68, 69]. GSTs are involved in the detoxification mechanisms, and 15 GST-

Table 3 Phenolic, flavonoid, tannin, and proline contents of $N$. linckia cultivated under different concentrations of nitrogen and sulfur (and combined $\mathrm{N}$ and $\mathrm{S}$ )

\begin{tabular}{|c|c|c|c|c|}
\hline Stress conditions & Lipid peroxidation (MDA nmol/g) & Protein concentration as $\mathrm{mg} / \mathrm{g}$ & Glutathione $S$-transferase in $\mu / \mathrm{g}$ tissue & Catalase activity (\%) \\
\hline \multicolumn{5}{|l|}{ Nitrogen (g/l) } \\
\hline 0 & $195.85 \pm 5.53^{\mathrm{c}}$ & $178.61 \pm 1.33^{\mathrm{c}}$ & $89.32 \pm 2.58^{\mathrm{d}}$ & $55.44 \pm 2.86^{\mathrm{c}}$ \\
\hline 1.5 & $109.67 \pm 4.91^{\mathrm{f}}$ & $252.58 \pm 1.23^{\mathrm{b}}$ & $81.04 \pm 3.73^{\mathrm{e}}$ & $40.90 \pm 2.52^{\mathrm{e}}$ \\
\hline 3 & $128.10 \pm 3.75^{\mathrm{e}}$ & $287.30 \pm 1.30^{\mathrm{a}}$ & $92.66 \pm 3.35^{\mathrm{c}}$ & $60.08 \pm 3.18^{\mathrm{b}}$ \\
\hline 6 & $227.65 \pm 6.74^{b}$ & $152.44 \pm 0.97^{\mathrm{d}}$ & $101.56 \pm 5.40^{\mathrm{b}}$ & $62.85 \pm 3.54^{\mathrm{b}}$ \\
\hline 12 & $666.22 \pm 9.07^{\mathrm{a}}$ & $55.66 \pm 1.52^{\mathrm{f}}$ & $375.62 \pm 7.35^{\mathrm{a}}$ & $72.99 \pm 3.00^{\mathrm{a}}$ \\
\hline $6 \mathrm{~g} / 1 \mathrm{~N}+0.3 \mathrm{~g} / 1 \mathrm{~S}$ & $143.57 \pm 5.50^{\mathrm{d}}$ & $140.06 \pm 1.03^{\mathrm{e}}$ & $89.86 \pm 3.80^{\mathrm{d}}$ & $44.77 \pm 4.57^{\mathrm{d}}$ \\
\hline \multicolumn{5}{|l|}{ Sulfur (g/l) } \\
\hline 0 & $328.79 \pm 7.90^{\mathrm{a}}$ & $207.78 \pm 1.35^{\mathrm{e}}$ & $246.86 \pm 0.51^{\mathrm{a}}$ & $40.84 \pm 2.46^{\mathrm{c}}$ \\
\hline 0.07 & $109.67 \pm 4.91^{\mathrm{f}}$ & $252.58 \pm 1.23^{\mathrm{d}}$ & $81.04 \pm 3.73^{\mathrm{e}}$ & $40.90 \pm 2.52^{\mathrm{c}}$ \\
\hline 0.15 & $170.12 \pm 5.42^{\mathrm{d}}$ & $270.24 \pm 1.02^{\mathrm{c}}$ & $147.06 \pm 4.40^{\mathrm{c}}$ & $41.10 \pm 2.35^{\mathrm{c}}$ \\
\hline 0.3 & $185.97 \pm 5.53^{\mathrm{c}}$ & $310.84 \pm 0.92^{\mathrm{b}}$ & $151.07 \pm 5.59^{\mathrm{c}}$ & $42.22 \pm 3.59^{\mathrm{c}}$ \\
\hline 0.6 & $209.89 \pm 7.37^{b}$ & $319.80 \pm 0.77^{\mathrm{a}}$ & $178.97 \pm 5.54^{\mathrm{b}}$ & $51.04 \pm 3.14^{\mathrm{a}}$ \\
\hline $6 \mathrm{~g} / 1 \mathrm{~N}+0.3 \mathrm{~g} / 1 \mathrm{~S}$ & $143.57 \pm 5.50^{\mathrm{e}}$ & $140.06 \pm 1.03^{\mathrm{f}}$ & $89.86 \pm 3.80^{\mathrm{d}}$ & $44.77 \pm 4.57^{\mathrm{b}}$ \\
\hline
\end{tabular}

Data are presented as means $\pm \mathrm{SD}(n=3)$ in each column, and for each concentration, means with different letters are significantly different $(p<0.05)$ 
like isoenzymes (Cr GSTS) were found in the model species of green alga Chlamydomonas reinhardtii [70].

Moreover, Zahang et al. [71] found that sulfur significantly enhanced the tolerance of oil seed rape exposed to Cr stress by activating several detoxification mechanisms such as the ascorbate-glutathione (AsA-GSH) enzyme defense system and GSH production. Kumaresan et al. [72] studied sulfur stress on Arthrospira sp. and reported that the alga was able to cope the stress by altering the gene expression that involved in sulfur metabolism and different sulfur-dependent pathways.

The combination of $\mathrm{N}$ and $\mathrm{S}$ provoked a significant reduction in all the parameters tested, compared to the produced maximal quantities at the same sulfur concentration, singly. It seems that the addition of nitrogen (in the combination with sulfur) may ameliorate the adverse effect of sulfur and the lipid peroxidation (MDA), as well as the other parameters of antioxidant enzymes in algal species under investigation.

\subsection{Effect of media compositions on the antioxidant activity of $N$. linckia under nitrogen and sulfur stress conditions}

Table 4 shows the antioxidant activity (\%) of $N$. linckia extracts $(200 \mathrm{ppm})$ cultivated under different nitrogen and sulfur concentrations (and combined effect with sulfur) using DPPH radical scavenging activity (after $30 \mathrm{~min}$ and $60 \mathrm{~min}$ ) and ABTS assay compared to synthetic antioxidant (BHT). Antioxidant activity was known to be concentration dependent. Nitrogen depletion $(0.0 \mathrm{~g} / \mathrm{l})$ provoked the significantly higher antioxidant activity by DPPH (30 min) which reached
$93.03 \pm 1.00$ and increased to $94.26 \pm 0.80$ at $1.5 \mathrm{~g} / 1 \mathrm{~N}$ (after $60 \mathrm{~min}$ ). The extract $12 \mathrm{~g} / 1 \mathrm{~N}$ recorded the highest antioxidant activity that might be resulted from its contents of flavonoids, tannins, and phenolic compounds represented in Table 2, as reported by Shalaby and Shanab [73] and Gaber et al. [74].

Concerning sulfur stress, the highest antioxidant activity occurred at $0.07 \mathrm{~g} / 1$ using DPPH assay $(91.25 \pm 1.09$ and $94.26 \pm 0.80$ after $30 \mathrm{~min}$ and $60 \mathrm{~min}$, respectively), whereas the activity using ABTS assay was $61 \pm 1.00$ at the concentration $0.3 \mathrm{~g} / 1$ while the activity increased using ABTS assay $(82.27 \pm 1.01)$. The combination of $6 \mathrm{~g} / 1 \mathrm{~N}$ and $0.3 \mathrm{~g} / \mathrm{l} \mathrm{S}$ induced a decrease in antioxidant activity using DPPH $(63.97 \pm 1.00$ and $69.19 \pm 0.72$ after $30 \mathrm{~min}$ and $60 \mathrm{~min}$, respectively) and a slight decrease in antioxidant activity using ABTS (82.27 \pm 0.82$)$.

ROS are products of a normal cellular metabolism and play vital roles in the stimulation of signaling pathways in plant and animal cells in response to changes in intracellular and extracellular environmental conditions. Increased regeneration of ROS occurred under stress conditions, the defense system in the form of low molecular weight substances (as ascorbic acid, $\beta$-carotene, glutathione), and/or antioxidant enzymes (superoxide dismutase/catalase/peroxidase/glutathione $S$-transferase) were produced in order to scavenge the ROS and avoid their harmful action on biomolecules and biomembranes.

Proteins, nucleic acids, and lipids were also significant targets for oxidative attack, and modification of these molecules can increase the risk of mutagenesis. Therefore, antioxidants are good scavengers for ROS and free radicals. In other words, it defends and protects cells from their harmful action. The
Table 4 Antioxidant activity $(\%)$ of $N$. linckia extracts (200 ppm) cultivated under different nitrogen concentrations (and combined effect with sulfur), using DPPH radical scavenging activity (after $30 \mathrm{~min}$ and $60 \mathrm{~min}$ ) and ABTS assay compared to synthetic antioxidant (BHT)

\begin{tabular}{llll}
\hline Stress conditions & DPPH $(\%), 30$ min & DPPH $(\%), 60$ min & ABTS $(\%)$ \\
\hline Nitrogen $(\mathrm{g} / \mathrm{l})$ & & & \\
0 & $93.03 \pm 1.00^{\mathrm{a}}$ & $91.18 \pm 0.42^{\mathrm{b}}$ & $69.76 \pm 0.68^{\mathrm{d}}$ \\
1.5 & $91.25 \pm 1.09^{\mathrm{b}}$ & $94.26 \pm 0.80^{\mathrm{a}}$ & $61 \pm 1.00^{\mathrm{f}}$ \\
3 & $63.14 \pm 0.79^{\mathrm{f}}$ & $65.51 \pm 0.42^{\mathrm{f}}$ & $43.34 \pm 0.65^{\mathrm{f}}$ \\
6 & $71.64 \pm 0.53^{\mathrm{e}}$ & $78.27 \pm 0.54^{\mathrm{d}}$ & $67.42 \pm 0.84^{\mathrm{e}}$ \\
12 & $87.08 \pm 0.77^{\mathrm{c}}$ & $89.10 \pm 0.65^{\mathrm{c}}$ & $84.03 \pm 0.94^{\mathrm{b}}$ \\
$6 \mathrm{~g} / 1 \mathrm{~N}+0.3 \mathrm{~g} / 1 \mathrm{~S}$ & $63.973 \pm 1.00^{\mathrm{f}}$ & $69.19 \pm 0.72^{\mathrm{e}}$ & $82.27 \pm 0.82^{\mathrm{c}}$ \\
BHT & $85.63 \pm 0.55^{\mathrm{d}}$ & $89.50 \pm 0.55^{\mathrm{c}}$ & $90.82 \pm 0.68^{\mathrm{a}}$ \\
Sulfur $(\mathrm{g} / \mathrm{l})$ & & & \\
0 & $81.12 \pm 0.82^{\mathrm{e}}$ & $89.02 \pm 0.26^{\mathrm{b}}$ & $55.29 \pm 0.61^{\mathrm{g}}$ \\
0.07 & $91.25 \pm 1.09^{\mathrm{a}}$ & $94.26 \pm 0.80^{\mathrm{a}}$ & $61 \pm 1.00^{\mathrm{f}}$ \\
0.15 & $68.17 \pm 0.65^{\mathrm{f}}$ & $69.04 \pm 1.03^{\mathrm{d}}$ & $86.34 \pm 0.83^{\mathrm{b}}$ \\
0.3 & $89.063 \pm 0.50^{\mathrm{b}}$ & $88.18 \pm 0.64^{\mathrm{b}}$ & $84.20 \pm 1.01^{\mathrm{c}}$ \\
0.6 & $83.56 \pm 0.51^{\mathrm{d}}$ & $83.18 \pm 1.04^{\mathrm{c}}$ & $66.03 \pm 0.84^{\mathrm{e}}$ \\
$6 \mathrm{~g} / 1 \mathrm{~N}+0.3 \mathrm{~g} / 1 \mathrm{~S}$ & $63.97 \pm 1.00^{\mathrm{g}}$ & $69.19 \pm 0.72^{\mathrm{d}}$ & $82.27 \pm 0.82^{\mathrm{d}}$ \\
BHT & $85.63 \pm 0.55^{\mathrm{c}}$ & $89.50 \pm 0.55^{\mathrm{b}}$ & $90.82 \pm 0.68^{\mathrm{a}}$ \\
\hline
\end{tabular}

Data are presented as means $\pm \mathrm{SD}(n=3)$ in each column, and for each treatment, means with different letters are significantly different $(p<0.05)$ 
antioxidants prevent damages in proteins, DNA (protect from mutation), and lipid peroxidation (protect plasma membrane) in living cells (normal cells).

In our results, the most effective extract that represented the highest antioxidant activity was $0.3 \mathrm{~g} / \mathrm{l} \mathrm{S}$, and it also contains a considerable quantity of phytochemicals recorded in Table 2. Our results were in agreement with Deyab et al. [75] who performed extraction of Dictyota dichotoma using successive extraction with solvents of increasing polarity (hexane, ethyl acetate, acetone, and methanol), revealing the presence of 6,9 , 4 , and 7 of phytochemical compounds, respectively. Flavonoids showed antimicrobial, antiviral, and antioxidant activities, while phenols have anticancer, antioxidant, antimicrobial, and antiviral activities, and quinones exhibited cytotoxic activity.

Additionally, our results were in parallel with those obtained by Jerez-Martel et al. [76] who screened the aqueous and methanolic extracts of several microalgae and cyanobacteria for their radical scavenging activity against the DPPH radical method. The methanol extracts showed compounds with a higher antioxidant activity. In addition, aqueous and methanolic extracts of microalgae Euglena cantabrica also exhibited the highest antioxidant activity, probably due to the presence of the high contents of phenolics.

From all the previous data, four promising extracts were selected $(0.3 \mathrm{~g} / 1 \mathrm{~S}, 0.15 \mathrm{~g} / 1 \mathrm{~S}, 12 \mathrm{~g} / 1 \mathrm{~N}, 0.3 \mathrm{~g} / 1$ $\mathrm{S}+6 \mathrm{~g} / 1 \mathrm{~N}$ ), and based on their antioxidant activity, these were tested for their anticancer, antimicrobial, and antiviral activities.

\subsection{Anticancer activity of promising extracts of N. linckia}

Anticancer activity of the four promising extracts $(0.3 \mathrm{~g} / \mathrm{S}$, $0.15 \mathrm{~g} / 1 \mathrm{~S}, 12 \mathrm{~g} / 1 \mathrm{~N}, 0.3 \mathrm{~g} / 1 \mathrm{~S}+6 \mathrm{~g} / \mathrm{l} \mathrm{N})$ was determined at different concentrations $(31.25 \mu \mathrm{g} / \mathrm{ml}, 62.5 \mu \mathrm{g} / \mathrm{ml}, 125 \mu \mathrm{g} / \mathrm{ml}$, $250 \mu \mathrm{g} / \mathrm{ml}$, and $500 \mu \mathrm{g} / \mathrm{ml}$ ) and tested against four cell line (lung, breast, colon, and cervical cancer cell lines) cytotoxicity. The obtained results revealed that $\%$ viability of cancer cells was inversely proportional to extract concentration as shown in Fig. 2.

The extract $0.3 \mathrm{~g} / 1 \mathrm{~S}$ showed the highest anticancer activity with the lowest $\mathrm{IC}_{50}(155 \mu \mathrm{g} / \mathrm{ml})$ against HCT 116 cell line, whereas $12 \mathrm{~g} / 1 \mathrm{~N}$ recorded the highest activity with $\mathrm{IC}_{50}(193$ $\mu \mathrm{g} / \mathrm{ml}$ ) against HeLa cell line. These results indicated that the effect of crude extracts on HCT 116 and HeLa cells is concentration dependent through the concentrations tested $(31.25-500 \mu \mathrm{g} / \mathrm{ml})$. This effect can be explained as receptor independent for these types of cells [77, 78]. The cytotoxic profile of the crude extract may be due to its content from bioactive compounds as recorded in Table 2 as there is a strong correlation between anticancer activity and phenolic, flavonoid, and tannin contents.
Anticancer results in this study were in parallel with those obtained by Alghazeer et al. [79], who evaluated the antioxidant activity and the potential inhibition of $\mathrm{CaCO}_{2}$ cell proliferation of crude extracts of Chlorophyta (Ulva lactuca and Codium tomentosum), Phaeophyta (Cystoseira crinita, Cystoseira stricta, and Sargassum vulgare), and Rhodophyta (Gelidium latifolium, Hypnea musciformis, and Jania rubens). They found that the polyphenol- and flavonoid-rich extracts showed remarkable reducing power and antiradical properties, after exposure of $\mathrm{CaCO}_{2}$ cells to various concentrations of extracts. The antiproliferative effect of algal extracts was correlated with their polyphenol and flavonoid contents.

\subsection{Antimicrobial activity of promising extracts of N. linckia}

The obtained results recorded in Table 5 revealed that the $\mathrm{G}$ -ve $K$. pneumoniae showed no activity (NA) with all the tested extracts while $E$. coli showed moderate activities only with $12 \mathrm{~g} / 1 \mathrm{~N}$ extract $(16.6 \pm 0.5 \mathrm{~mm})$ and $0.3 \mathrm{~g} / \mathrm{l} \mathrm{S}+6 \mathrm{~g} / \mathrm{l} \mathrm{N}$ $(14.6 \pm 0.6 \mathrm{~mm})$ of $N$. linckia. The G+ve strains $S$. aureus and $S$. mutans showed variable activities $(13.3-21.0 \mathrm{~mm})$ with all the extracts except that of $12 \mathrm{~g} / 1 \mathrm{~N}$ where no activity was recorded. Sulfur-containing extracts $(0.3 \mathrm{~g} / 1$ and $0.15 \mathrm{~g} / \mathrm{l})$ showed higher activities with $S$. aureus and $S$. mutans (19.0 $\mathrm{mm}, 19.3 \mathrm{~mm}$, and $21.0 \mathrm{~mm}$ ).

Concerning antifungal, $A$. niger showed NA with any tested extract, while $C$. albicans yeast showed low to moderate activity (11.0-14.6 mm) with three extracts except that of $6 \mathrm{~g} / 1$ $\mathrm{N}$ of $N$. linckia which showed no activity with the yeast.

The antimicrobial activity of $N$. linckia cultivated under $\mathrm{S}$, $\mathrm{N}$, and $\mathrm{S}$ combined with $\mathrm{N}$ concentration may be due to the types and content of secondary metabolites which were synthesized during algal cultivation under those stresses.

The most effective extract was $0.15 \mathrm{~g} / \mathrm{l} \mathrm{S}$ against the most susceptible bacterial strain (S. aureus), and this is may be due to high contents of phenolic, flavonoid, and tannin as represented in Table 2, which was in a good agreement with Seetharaman et al. [80], who evaluated antibacterial activity against some human clinically isolated pathogens (Pseudomonas aeruginosa, Escherichia coli, Staphylococcus aureus, Bacillus cereus, Proteus vulgaris, and Bacillus subtilis). The phytochemical analysis also showed the presence of alkaloids, saponin, phenols, terpenoids, coumarins, flavonoids, tannins, protein, and carbohydrates and absence of glycosides, steroids, and anthraquinone.

Our results were in parallel with those of Sujatha et al. [81], who investigated phytochemical screening and antibacterial efficacy of various solvent extracts of marine algae such as Sargassum swartzii against some selected human and fish pathogenic bacteria. The maximum bioactive compounds were present in the ethanolic extract, and the minimum bioactive compounds were present in aqueous extract. The ethanol 
Fig. $2 \mathrm{IC}_{50}$ as $\mu \mathrm{g} / \mathrm{ml}$ of algal extracts against four cell lines

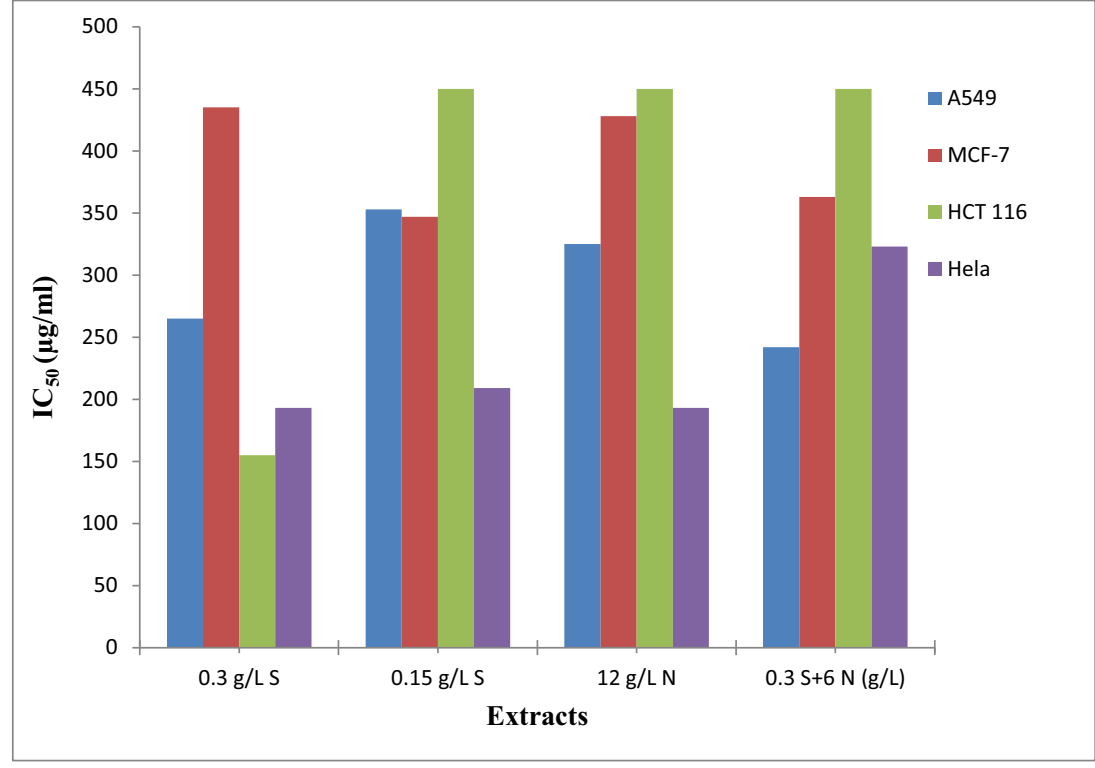

extract was significantly higher in phenolic content (15.35 \pm $2.61 \mathrm{mg}$ of $\mathrm{GAE} / \mathrm{g}$ ), and the methanolic extract was significantly higher in flavonoid content $(26.92 \pm 7.14 \mathrm{mg}$ of QE/g). In human pathogen, the highest antibacterial activity was against Pseudomonas aeruginosa $(18.00 \pm 0.00 \mathrm{~mm})$ and the fish pathogen was significantly higher against Aeromonas hydrophila.

\subsection{Antiviral activity of $N$. linckia against $\left(\mathrm{H}_{5} \mathrm{~N}_{1}\right)$ influenza virus}

Antiviral activity of the four promising extracts was tested against influenza virus (M7217B) $2013\left(\mathrm{H}_{5} \mathrm{~N}_{1}\right)$. Data recorded in Table 6 revealed that the extract $0.3 \mathrm{~g} / 1 \mathrm{~S}$ has the maximum inhibition of $50.0 \%$ and $63.6 \%$ at $7 \mu \mathrm{g} / \mathrm{ml}$ and 28 $\mu \mathrm{g} / \mathrm{ml}$, respectively, followed by $0.15 \mathrm{~g} / \mathrm{l} \mathrm{S}$ which induced $29.5 \%$ and $66 \%$ at $7 \mu \mathrm{g} / \mathrm{ml}$ and $28 \mu \mathrm{g} / \mathrm{ml}$ with cytotoxicity on MDCK cells, $\mathrm{IC}_{50}$, less than $7 \mu \mathrm{g} / \mu \mathrm{l}$ and $29.5 \mu \mathrm{g} / \mu \mathrm{l}$, respectively. The highest antiviral activity against $\mathrm{H}_{5} \mathrm{~N}_{1}$ might be due to bioactive compounds such as high phenolic, flavonoid, and tannin contents in the extract as represented in Table 2, which were $47.32 \mathrm{mg} / \mathrm{g}$ and $44.94 \mathrm{mg} / \mathrm{g}$ for phenolic contents, $10.91 \mathrm{mg} / \mathrm{g}$ and $14.56 \mathrm{mg} / \mathrm{g}$ for flavonoid contents, and $13.77 \mathrm{mg} / \mathrm{g}$ and $8.53 \mathrm{mg} / \mathrm{g}$ for tannin contents.

Over the last few decades, natural products have been studied for anti-infective and, more specifically, antiviral activities. Basic researches in experimental models using various biological systems strongly suggested the protective role of plant-derived natural compounds against different viral infections [82]. Some natural and synthetic compounds can

Table 5 Antimicrobial activity as mm inhibition zone of the selected promising extracts (according to antioxidant activity result) of $N$. linckia against different bacterial and fungal strains using disc diffusion assay

\begin{tabular}{|c|c|c|c|c|c|c|c|}
\hline \multirow[t]{2}{*}{ Microorganism } & \multicolumn{4}{|l|}{ Extracts } & \multicolumn{3}{|c|}{ Standard antibiotic } \\
\hline & $0.3 \mathrm{~g} \mathrm{~S}$ & $0.3 \mathrm{~g} \mathrm{~S}+6 \mathrm{~g} \mathrm{~N}$ & $0.15 \mathrm{~g} \mathrm{~S}$ & $12 \mathrm{~g} \mathrm{~N}$ & Gentamicin & Ampicillin & Nystatin \\
\hline \multicolumn{8}{|l|}{ Gram-negative bacteria } \\
\hline Escherichia coli (ATCC: 9637) & NA & $14.6 \pm 0.6^{\mathrm{c}}$ & NA & $16.6 \pm 0.5^{\mathrm{b}}$ & $27 \pm 0.5^{\mathrm{a}}$ & NT & NT \\
\hline Klebsiella pneumoniae (ATCC: 10031) & NA & NA & NA & NA & $25 \pm 0.5^{\mathrm{a}}$ & NT & NT \\
\hline \multicolumn{8}{|l|}{ Gram-positive bacteria } \\
\hline Staphylococcus aureus (ATCC: 6538) & $21.0 \pm 1.0^{\mathrm{b}}$ & $14.6 \pm 0.5^{\mathrm{d}}$ & $19.0 \pm 1.0^{\mathrm{c}}$ & NA & NT & $22 \pm 0.1^{\mathrm{a}}$ & NT \\
\hline Streptococcus mutans (ATCC: 25175) & $19.3 \pm 0.6^{\mathrm{b}}$ & $19.6 \pm 0.6^{\mathrm{b}}$ & $13.3 \pm 0.5^{\mathrm{c}}$ & NA & NT & $30 \pm 0.5^{\mathrm{a}}$ & NT \\
\hline \multicolumn{8}{|l|}{ Fungi } \\
\hline Candida albicans (ATCC: 10231) & $11.0 \pm 1.0^{\mathrm{d}}$ & $13.6 \pm 0.5^{\mathrm{c}}$ & $14.6 \pm 0.6^{\mathrm{b}}$ & NA & NT & NT & $21 \pm 0.5^{2}$ \\
\hline Aspergillus niger (ATCC: 32856) & NA & NA & NA & NA & NT & NT & $20 \pm 0.5$ \\
\hline
\end{tabular}

Data are presented as means $\pm \mathrm{SD}(n=3)$ in each column, and for each extract, means with different letters are significantly different $(p<0.05)$

$N A$ no activity, $N T$ not tested 
Table 6 Antiviral activity (as \% and $\mathrm{IC}_{50}$ ) of different algal extracts against $\mathrm{H}_{5} \mathrm{~N}_{1}$ virus using plaque reduction assay

\begin{tabular}{|c|c|c|c|c|c|}
\hline Algal sample & Conc. $(\mu \mathrm{g} / \mathrm{ml})$ & Initial viral count $(\mathrm{PFU} / \mathrm{ml})$ & Viral count $(\mathrm{PFU} / \mathrm{ml})$ & $\%$ of inhibition & Cytotoxicity $\mathrm{IC}_{50}(\mu \mathrm{g} / \mu \mathrm{l})$ \\
\hline $12 \mathrm{~g} / 1 \mathrm{~N}$ & $\begin{array}{l}7 \\
28\end{array}$ & $\begin{array}{l}4.4 \times 10^{8} \\
4.4 \times 10^{8}\end{array}$ & $\begin{array}{l}2.7 \times 10^{8} \\
2.3 \times 10^{8}\end{array}$ & $\begin{array}{l}38.6 \\
47.7\end{array}$ & 19.5 \\
\hline $0.3 \mathrm{~g} / 1 \mathrm{~S}$ & $\begin{array}{l}7 \\
28\end{array}$ & $\begin{array}{l}4.4 \times 10^{8} \\
4.4 \times 10^{8}\end{array}$ & $\begin{array}{l}2.2 \times 10^{8} \\
1.6 \times 10^{8}\end{array}$ & $\begin{array}{l}50 \\
63.6\end{array}$ & Less than $7 \mu \mathrm{g} / \mu \mathrm{l}$ \\
\hline $0.3 \mathrm{~g} / 1 \mathrm{~S}+6 \mathrm{~g} / 1 \mathrm{~N}$ & $\begin{array}{l}7 \\
28\end{array}$ & $\begin{array}{l}4.4 \times 10^{8} \\
4.4 \times 10^{8}\end{array}$ & $\begin{array}{l}3.7 \times 10^{8} \\
2.7 \times 10^{8}\end{array}$ & $\begin{array}{l}16 \\
38.6\end{array}$ & Less than $7 \mu \mathrm{g} / \mu \mathrm{l}$ \\
\hline $0.15 \mathrm{~g} / 1 \mathrm{~S}$ & $\begin{array}{l}7 \\
28\end{array}$ & $\begin{array}{l}4.4 \times 10^{8} \\
4.4 \times 10^{8}\end{array}$ & $\begin{array}{l}3.1 \times 10^{8} \\
1.5 \times 10^{8}\end{array}$ & $\begin{array}{l}29.5 \\
66\end{array}$ & 29.5 \\
\hline
\end{tabular}

prevent, suppress, or reverse the progression of virus infection. Natural products have been proven to be the most effective in terms of their ability to act as an antiviral.

Our results were in agreement with those reported by Pereira et al. [83], who tested the antiviral effect of the $\mathrm{CH}_{2} \mathrm{Cl}_{2} / \mathrm{MeOH}$-soluble fraction from the alga Dictyota menstrualis on HIV-1 replication in vitro. They found that the antiviral activity was attributed to two diterpenes: $(6 R)$ 6-hydroxydichotoma-3,14-diene-1,17-dial, named Da-1, and (6R)-6-acetoxidichotoma-3,14-diene-1,17-dial.

Additionally, our results were in parallel with those of Carpine and Sieber [14] who found that Nostoc linckia have high potential for use as an antiviral agent against influenza virus and could be promising as anti-coronavirus (SARSCoV-2).

It was obviously clear that alga cultivated under sulfur stress $(0.3 \mathrm{~g} / 1 \mathrm{~S})$ recorded almost the promising biological activities as (i) antioxidant activity based on DPPH and ABTS assays, respectively (88.18 $\pm 0.64 \%$ and $84.20 \pm 1.01 \%$ ); (ii) anticancer activity with the lowest $\mathrm{IC}_{50}(155 \mu \mathrm{g} / \mathrm{ml})$ against $\mathrm{HCT} 116$ cell line; (iii) antibacterial activity $(21.0 \pm 1.0$ as $\mathrm{mm}$ inhibition zone against Staphylococcus aureus and $19.3 \pm 0.6$ against Streptococcus mutans); and (iv) antiviral activity against $\mathrm{H}_{5} \mathrm{~N}_{1}$ virus with a percentage of inhibition of $50 \%$ and $63.6 \%$ at a concentration of $7 \mu \mathrm{g} / \mathrm{ml}$ and 28 $\mu \mathrm{g} / \mathrm{ml}$, respectively, with cytotoxicity less than $7 \mu \mathrm{g} / \mu \mathrm{l}$. These results may be correlated with the presence of bioactive compounds recorded in Table 7 as antioxidant, antimicrobial, anticancer, and antiviral compounds such as cyclohexasiloxane, dodecamethyl, cycloheptasiloxane, tetradecamethyl, 2-hexadecen-1-ol, 3,7,11,15tetramethyl-, [r-[r*,r*-(e)]]-4h-1-benzopyran-4-one, 2-(3,4-dimethoxyphenyl)-3,5-dihydroxy-7-methoxy-, 2hexadecanol, hexadecanoic acid, and methyl ester. These observations were in agreement with the previously published results $[84,88,90,91]$. Also, the obtained results correlated with the data in Table 2; there is a strong correlation between the biological activity of the promising crude extract $(0.3 \mathrm{~g} / 1 \mathrm{~S})$ and the concentration of flavonoids (10.91 $\pm 0.72 \mathrm{mg}$ of rutin/ $\mathrm{g}$ DW), phenolic compounds (47.32 $\pm 0.58 \mathrm{mg}$ gallic acid equivalent/g), and tannin $(13.77 \pm 0.58 \mathrm{mg}$ tannic acid equivalent/g DW).

\section{Conclusion}

The cyanobacterium Nostoc linckia was investigated under $\mathrm{N}$ and $\mathrm{S}$ stress conditions. Different concentrations of nitrogen and sulfur were used depending on their content in the BG-11 10 nutritive medium. Four promising crude extracts $(0.15 \mathrm{~g} / 1 \mathrm{~S}, 0.3 \mathrm{~g} / 1 \mathrm{~S}, 12 \mathrm{~g} / 1 \mathrm{~N}$, and the combination of both elements $[0.3 \mathrm{~g} / 1 \mathrm{~S}+6 \mathrm{~g} / \mathrm{l}]$ ) were selected based on their antioxidant activity. Growth of the cyanobacterium was monitored as OD and DW, algal pigments (chlorophylls, carotenoids, and phycobiliproteins), antioxidant enzymes, lipid peroxidation, and phytochemical active substances were screened spectrophotometrically and determined by GC-MS analysis. Biological activities were determined (antimicrobial, antioxidant, antiviral, and anticancer activities), as well as the $\mathrm{IC}_{50}$. The obtained results generally illustrated that $0.3 \mathrm{~g} / 1 \mathrm{~S}$ extract showed the greatest biological activities. Enhancement in growth, pigment production, antioxidant enzymes, phytochemical screening, and the GC-MS analysis revealed that this extract contains several bioactive compounds which attributed all the recorded biological activities. A strong correlation was noticed between the promising sulfur extract $(0.3 \mathrm{~g} / \mathrm{l})$ and the content of phenolic compounds, flavonoids, tannins, and phycobiliproteins which may have a role in the recorded biological activities. It was known from the literatures that algae and cyanobacteria cultured under abiotic stress as the nutrient stress conditions altered its normal metabolic pathways towards the production of important substances and secondary metabolites that exhibit pronounced biological activities and can be isolated and be used as active ingredients in pharmaceutical drugs and have a role in medicine in curing many serious diseases. 


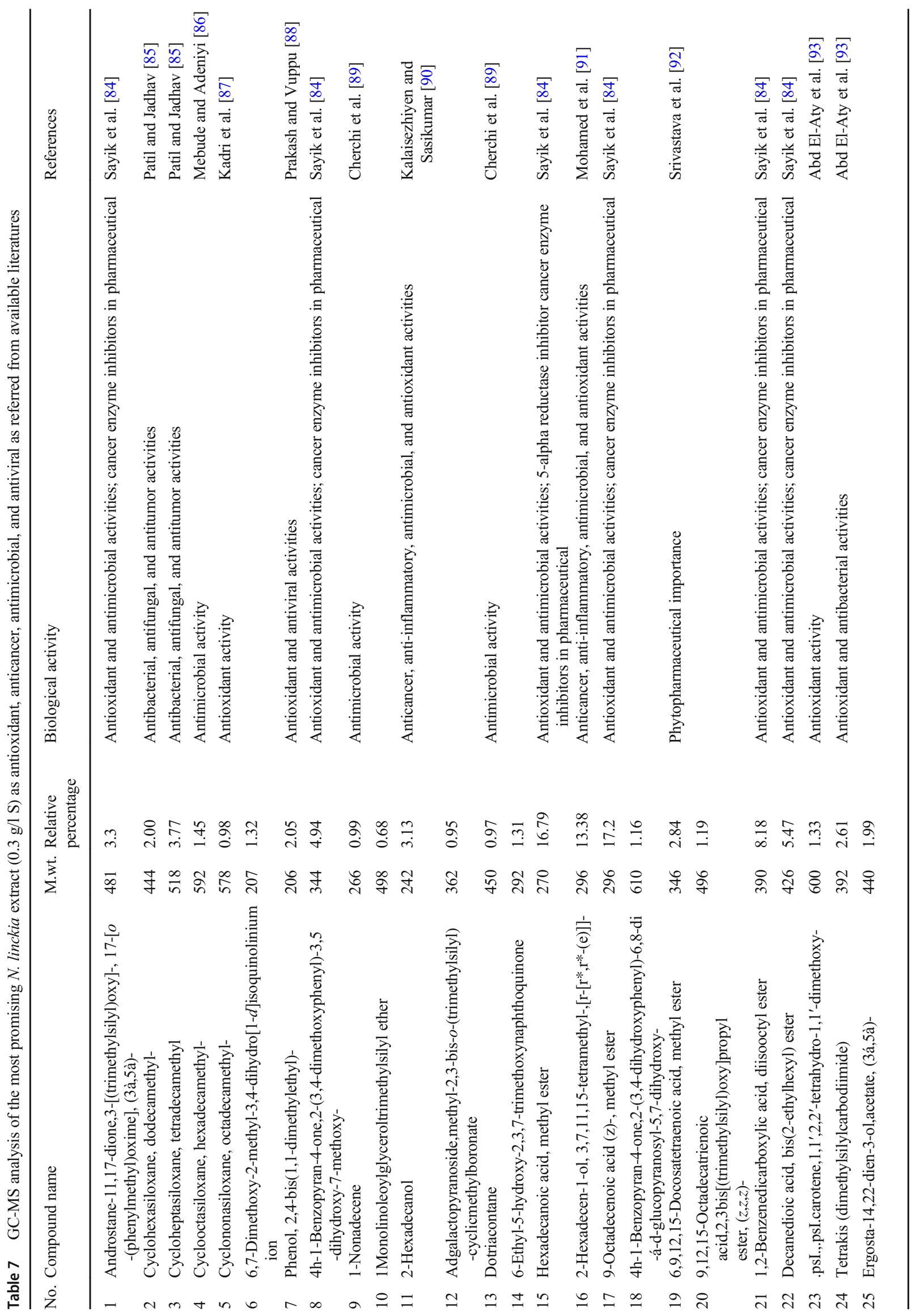


Author contribution All authors read and approved the final manuscript.

Data availability The data used and analysed in this study are available from the corresponding author on reasonable request.

\section{Declarations}

Ethics approval and consent to participate Not applicable in this section.

Competing interests The authors declare no competing interests.

\section{References}

1. Hitzfeld BC, Höger SJ, Dietrich DR (2000) Cyanobacterial toxins: removal during drinking water treatment, and human risk assessment. Environ Health Perspect 108:113-122

2. Komarek J, Kaštovský J, Mares J, Johansen JR (2014) Taxonomic classification of cyanoprokaryotes (cyanobacterial genera), using a polyphasic approach. Preslia 86(4):295-335

3. Barbosa MJ, Wijffels RH (2013) In: Richmond A, Hu Q (eds) Biofuels from microalgae. In: Handbook of microalgal culture, 2nd edn. John Wiley \& Sons, Hoboken, NJ, USA, pp 566-577

4. Wijffels RH, Barbosa MJ, Eppink MHM (2010) Microalgae for the production of bulk chemicals and biofuels. Biofuels Bioprod Biorefin 4:287-295

5. Hongsthong A, Bunnag B (2009) In: Gault PM, Marler HJ (eds) Overview of Spirulina: biotechnological, biochemical and molecular biological aspects. In: Handbook on cyanobacteria: biochemistry, biotechnology and applications. Nova Science Publishers, New York, NY, USA, pp 51-103

6. Vanthoor-Koopmans, M.; Cordoba-Matson, M.V.; ArredondoVega, B.O.; Lozano-Ramírez, C.; Garcia-Trejo, J.F.; RodriguezPalacio, M.C. (2014). Microalgae and cyanobacteria production for feed and food supplements. In Biosystems engineering: biofactories for food production in the century XXI.; GuevaraGonzalez, R., Torres-Pacheco, I., Eds.; Springer: Cham, Switzerland, pp. 253-275.

7. Singh JS, Kumar A, Rai AN, Singh DP (2016) Cyanobacteria: a precious bio-resource in agriculture, ecosystem, and environmental sustainability. Front Microbiol 7:529

8. Mourelle ML, Gómez CP, Legido JL (2017) The potential use of marine microalgae and cyanobacteria in cosmetics and thalassotherapy. Cosmetics 4:46

9. Ali HEA, El-fayoumy EA, Rasmy WE, Soliman RM, Abdullah MA (2020) Two-stage cultivation of Chlorella vulgaris using light and salt stress conditions for simultaneous production of lipid, carotenoids, and antioxidants. J Appl Phycol:1-13

10. El-fayoumy EA, Shanab SM, Shalaby EA (2020) Metabolomics and biological activities of Chlorella vulgaris grown under modified growth medium (BG11) composition. CMU J Nat Sci 19:91-123

11. El-Fayoumy EA, Shanab SM, Gaballa HS, Tantawy MA, Shalaby EA (2021) Evaluation of antioxidant and anticancer activity of crude extract and different fractions of Chlorella vulgaris axenic culture grown under various concentrations of copper ions. BMC Complementary Medicine and Therapies 21(1):1-16

12. Shanab SM, Mostafa SS, Shalaby EA, Mahmoud GI (2012) Aqueous extracts of microalgae exhibit antioxidant and anticancer activities. Asian Pac J Trop Med 2:608-615

13. Shalaby EA, Shanab SMM, Singh V (2010) Salt stress enhancement of antioxidant and antiviral efficiency of Spirulina platensis. J Med Plant Res 4(24):2622-2632
14. Carpine R, Sieber S (2021) Antibacterial and antiviral metabolites from cyanobacteria: their application and their impact on human health. Current Research in Biotechnology 3:65-81

15. Priya VM, Ramesh K (2021) Optimization of process parameters of the growth of Chlorella vulgaris for the production of biodiesel feedstock (microbial lipid) using sago wastewater as substrate. Biomass Conv Bioref 2021. https://doi.org/10.1007/s13399-02101401-4

16. Borowitzka MA, Moheimani NR (2013) Sustainable biofuels from algae. Mitig Adapt Strateg Glob Chang 18(1):13-25

17. Shah SMU, Abdullah MA (2018) Effects of macro/micronutrients on green and brown microalgal cell growth and fatty acids in photobioreactor and open-tank systems. Biocatal Agric Biotechnol 14:10-17

18. Sun X, Cao YY, Xu H, Liu Y, Sun J, Qiao D, Cao Y (2014) Effect of nitrogen-starvation, light intensity and iron on triacylglyceride/ carbohydrate production and fatty acid profile of Neochloris oleoabundans HK-129 by a two-stage process. Bioresour Technol 155:204-212

19. Zappi M, Bajpai R, Hernandez R, Mikolajczyk A, Lord Fortela D, Sharp W, Revellame E (2019) Microalgae culturing to produce biobased diesel fuels: an overview of the basics, challenges, and a look toward a true biorefinery future. Ind Eng Chem Res 58:1572415746

20. Kessler D (2006) Enzymatic activation of sulfur for incorporation into biomolecules in prokaryotes. FEMS Microbiol Rev 30:825840

21. Giordano M, Pezzoni V, Hell R (2000) Strategies for the allocation of resources under sulfur limitation in the green alga Dunaliella salina. Plant Physiol 124:857-864

22. Edge R, Truscott TG (2010) Properties of carotenoid radicals and excited states and their potential role in biological systems. In: Landrum JT (ed) Carotenoids: physical, chemical, and biological functions and properties. CRC Press, Boca Raton, FL, USA, pp 283-308

23. Wani TA, Wani SM, Ahmad M, Ganil A, Masoodi FA (2016) Bioactive profile, health benefits and safety evaluation of sea buckthorn (Hippophae rhamnoides L.): a review. Cogent Food Agric 2: 1128519

24. Prescott GW (1982) Algae of the Western Great Lakes area. W.M.C. Brown Publishers, Dubuque, Iowa, pp 1-977

25. Andersen RA (ed) (2005) Algal culturing techniques. Phycological Society of America, Academic Press in an imprint of Elsevier. Academic Press, New York, $578 \mathrm{p}$

26. Talukdar J (2012) Influences of dissolved inorganic carbon and nitrogen sources on growth, total lipid content and calorific value of freshwater oleaginous microalga Ankistrodesmus falcatus (Corda) Ralfs. Environ Eng Manag J 61:14-25

27. Rodríguez-Sánchez R, Ortiz-Butrón R, Blas-Valdivia V, Hernández-García A, Cano-Europa E (2012) Phycobiliproteins or C-phycocyanin of Arthrospira (Spirulina) maxima protect against $\mathrm{HgCl}_{2}$-caused oxidative stress and renal damage. Food Chem 135(4):2359-2365

28. Taga MS, Miller EE, Pratt DE (1984) Chia seeds as a source of natural lipid antioxidants. J Am Oil Chem Soc 61:928-931

29. Quettier DC, Gressier B, Vasseur J, Dine T, Brunet C, Luyckx MC, Cayin JC, Bailleul F, Trotin F (2000) Phenolic compounds and antioxidant activities of buckwheat (Fagopyrum esculentum Moench) hulls and flour. J Ethnopharmacol 72:35-42

30. Broadhurst RB, Jones WT (1978) Analysis of condensed tannins using acidified vanillin. J Sci Food Agric 29:788-794

31. Rausch T (1981) The estimation of microalgal protein content and its meaning to the evaluation of algal biomass I. Hidrobiologia 78: $237-251$ 
32. Lowry H, Rosebrough NJ, Farr AL, Randall RJ (1951) Protein measurement with the Folin phenol reagent. J Biol Chem 193: 265-275

33. Aebi H (1984) Catalase in vitro. Methods Enzymol 105:121-126

34. Fossati P, Prencipe L, Berti G (1980) Use of 3,5-dichloro-2-hydroxy benzene sulfonic acid/4-aminophenazone chromogenic system in direct enzymic assay of uric acid in serum and urine. Clin Chem 26(2):227-231

35. Habig W, Pabst M, Jakoby WJ (1974) Glutathione S-transferases. The first enzymatic step in mercapturic acid formation. Biol Chem 249:7130-7139

36. Ohkawa H, Ohishi N, Yagi K (1979) Assay for lipid peroxidation in animal tissues by thiobarbituric acid reaction. Anal Biochem 95: 351-358

37. Yen GC, Chen HY (1995) Antioxidant activity of various tea extracts in relation to their antimutagenecity. Journal of Agriculture. Food Chem 43:27-37

38. Re, R., Pellegrini, N., Proteggente, A., Pannala, A., Yang, M., RiceEvans, C. (1999). Antioxidant activity applying improved ABTS radical cation decolorization assay. Free Radic Biol Med, 26 (9-10): 1231-1237.

39. Dharmendra K, Maurya NN (2011) Anticancer property of gallic acid in A549, a human lung adenocarcinoma cell line, and possible mechanisms. J Clin Biochem Nutr 48(1):85-90

40. Ranganathan S, Halagowder D, Sivasithambaram ND (2015) Quercetin suppresses twist to induce apoptosis in MCF-7 breast cancer cells. PLoS One 10(10):e0141370

41. Scott AC (1989) Laboratory control of antimicrobial therapy. In: Collee JG et al (eds) Practical medical microbiology, 13th edn. Churchill Livingstone, Edinburgh, p 161

42. Martin GR (1981) Isolation of a pluripotent cell line from early mouse embryos cultured in medium conditioned by teratocarcinoma stem cells. Proc Natl Acad Sci 78(12):7634-7638.

43. Oxoid (1982) Manual of culture media, ingredients and other laboratory services. Published by Oxoid Limited Wade Road Basingstoke Hampshire, RG24OPW,UK

44. Mosmann T (1983) Rapid colorimetric assay for cellular growth and survival: Application to proliferation and cytotoxicity assays. J Immunol Methods (65:)1-2,55-63

45. Hayden FG, Cote KM, Douglas RG (1980) Plaque inhibition assay for drug susceptibility testing of influenza viruses. Antimicrobial. Agents and Chemotherapy 17:865-870

46. Solovchenko A, Gorelova O, Karpova O, Selyakh I, Semenova L, Chivkunova O, Baulina O, Vinogradova E, Pugacheva T, Scherbakov P, Vasilieva S, Lukyanov A, Lobakova E (2020) Phosphorus feast and famine in cyanobacteria: is luxury uptake of the nutrient just a consequence of acclimation to its shortage? Cells 9:1933. https://doi.org/10.3390/cells9091933

47. Koksharova OA, Butenko IO, Pobeguts OV, Safronova NA, Govorun VM (2020) The first proteomic study of Nostoc sp. PCC 7120 exposed to cyanotoxin BMAA under nitrogen starvation. Toxins 12:310. https://doi.org/10.3390/toxins12050310

48. Zalutskaya Z, Filina V, Ostroukhova M, Ermilova E (2018) Regulation of alternative oxidase 1 in Chlamydomonas reinhardtii during sulfur starvation. Eur J Protistol 63:26-33

49. Carfagna S, Salbitani G, Bottone C, De Marco A, Vana V (2015) Cross-effect of nitrogen and sulfur starvation in Chlorella sorokiniana 211/8K. Nat Res Forum 6:221-229

50. Balaguer L, Manrique E, Ascaso C (1997) Predictability of the combined effects of sulphur dioxide and nitrate on the green-algal lichen Ramalina farinacea. Can J Bot 75:1836-1842

51. Gantt E (1981) Phycobilisomes. Annu Rev Plant Physiol 32:327347

52. Yamanaka C, Glazer AN (1980) Dynamic aspects of phycobilisome structure. Phycobilisome turnover during nitrogen starvation in Synechococcus sp Archives of Microbiology 124:39 47

53. Johnson EM, Kumar K, Das D (2014) Physicochemical parameters optimization and purification of phycobiliproteins from the isolated Nostoc sp. Bioresour Technol 166:541-547

54. Nayak M, Suh WI, Chang YK, Lee B (2019) (2019). Exploration of two-stage cultivation strategies using nitrogen starvation to maximize the lipid productivity in Chlorella sp. HS2. Bioresour. Technol. 276:110-118

55. Loaiza NR, Vera P, Aiello-Mazzarri C, Morales E (2015) Comparative growth and biochemical composition of four strains of Nostoc and Anabaena (cyanobacteria, Nostocales) in relation to sodium nitrate. Acta Biologica Colombiana 21(2):347-354

56. Zhao C, Höppner A, Xu QZ, Gärtner W, Scheer H, Zhou M, Zhao KH (2017a) Structures and enzymatic mechanisms of phycobiliprotein lyases $\mathrm{CpcE} / \mathrm{F}$ and $\mathrm{PecE} / \mathrm{F}$. Proc Natl Acad Sci U S A 114(50):13170-13175

57. Zhao L-S, Li K, Wang Q-M, Song X-Y, Su H-N, Xie B-B, Zhang X-Y, Huang F, Chen X-L, Zhou B-C (2017b) Nitrogen starvation impacts the photosynthetic performance of Porphyridium cruentum as revealed by chlorophyll a fluorescence. Sci Rep 7:8542

58. Li J, Zhu Z, Gerendás J (2008) Effects of nitrogen and sulfur on total phenolics and antioxidant activity in two genotypes of leaf mustard. J Plant Nutr 31:1642-1655

59. Al-Rashed SA, Ibrahim MM, El-Gaaly GA, Al-Shehri S, Mostafa A (2016) Evaluation of radical scavenging system in two microalgae in response to interactive stresses of UV-B radiation and nitrogen starvation. Saudi Journal of Biological Sciences 23(6):706-712

60. Chokshi K, Pancha I, Ghosh A, Mishra S (2017) Nitrogen starvation induced cellular crosstalk of ROS-scavenging antioxidants and phytohormone enhanced the biofuel potential of green microalga Acutodesmus dimorphus. Biotechnology for biofuels 10:2-12

61. Hamid S, Sibi G (2018) Antioxidant system response in green microalga Chlorococcopsis minuta against nutrient stress in growth media. Asian Journal of biological Science 11(4):210-216

62. Allahdadi M, Farzane P (2018) Influence of different levels of nitrogen fertilizer on some phytochemical characteristics of artichoke (Cynara scolymus L.) leaves. Journal of Medicinal Plants Studies 6(1):109-115

63. Lauritano C, Deluca D, Amoroso M, Benfatto S, Maestri S, Racioppi C, Esposito F, Lanora A (2019) New molecular insights on the response of the green alga Tetraselmis suecica to nitrogen starvation. Sci Rep 9:3336

64. Tóth T, Bystrická J, Tomáš J, Siekel P, Kovarovič J, Lenková M (2018) Effect of sulphur fertilization on contents of phenolic and sulphuric compounds in onion (Allium cepa L.). Journal of Food and Nutrition Research 57(2):170-178

65. Pancha, I., Chokshi, K., George, B., Ghosh, T., Paliwal, C., Maurya, R., Mishra, S. (2014). Nitrogen stress triggered biochemical and morphological changes in the microalgae Scenedesmus sp. CCNM 1077. Bioresource Technology, 156: 146-154.

66. Menegol T, Diprat AB, Rodrigues E, Rech R (2017) Effect of temperature and nitrogen concentration on biomass composition of Heterochlorella luteoviridis. Food Science and Technology, Campinas 37:28-37

67. Bose J, Rodrigo-Moreno A, Shabala S (2014) ROS homeostasis in halophytes in the context of salinity stress tolerance. J Exp Bot 65(5):1241-1257

68. Khan, M.I.R., Asgher, M., Iqbal, N., Khan, N.A. (2013) Potentiality of sulphur-containing compounds in salt stress tolerance ecophysiology and responses of plants under salt stress (Springer), pp. 443-472.

69. Kumar S, Trivedi PK (2018) Glutathione S-transferases: role in combating abiotic stresses including arsenic detoxification in plants. Front Plant Sci 9:751 
70. Chatzikonstantinou M, Vlachakis D, Chronopoulou E, Papageorgiou L, Papageorgiou AC, Labrou NE (2017) The glutathione transferase family of Chlamydomonas reinhardtii: identification and characterization of novel sigma class-like enzymes. Algal Res 24:237-250

71. Zahang S, Caol L, Wang ZR, Li Z, Ma J (2018) Anti-cancer effect of toosendanin and its underlying mechanisms. J Asian Nat Prod Res 9:1-13

72. Kumaresan V, Nizam F, Ravichandran G, Viswanathan K, Palanisamy R, Bhatl P, Arasu MV, Al-Dhabi NA, Mala K, Arockiaraj J (2017) Transcriptome changes of blue green algae, Arthrospira sp. in response to sulfate stress. Algal Res 23:96-103

73. Shalaby EA, Shanab SMM (2013) Comparison of DPPH and ABTS assays for determining antioxidant potential of water and methanol extracts of Spirulina platensis. Indian Journal of GeoMarine Sciences 42(5):556-564

74. Gaber NB, El-Dahy SI, Shalaby EA (2021) Comparison of ABTS, DPPH, permanganate, and methylene blue assays for determining antioxidant potential of successive extracts from pomegranate and guava residues. Biomass Conv Bioref. https://doi.org/10.1007/ s13399-021-01386-0

75. Deyab M, Elkatony T, Ward F (2016) Qualitative and quantitative analysis of phytochemical studies on brown seaweed, Dictyota dichotoma. Int J Eng Res Dev 4(2):674-678

76. Jerez-Martel, I., García-Poza, S., Rodríguez-Martel, G., Rico, M., Afonso-Olivares, C., Gómez-Pinchetti, J.L. (2017). Phenolic profile and antioxidant activity of crude extracts from microalgae and cyanobacteria strains. J Food Qual, 8 pages, 2017, 1, 8.

77. Aboul-Enein AM, Shanab SM, Shalaby EA, Zahran MM, Lightfoot DA, El-Shemy HA (2014) Cytotoxic and antioxidant properties of active principals isolated from water hyacinth against four cancer cells lines. BMC Complement Altern Med 14:397. https://doi.org/ 10.1186/1472-6882-14-397

78. Westerink WMA, Schoonen WGAJ (2007) Cytochrome P450 enzyme levels in HepG2 cells and cryopreserved primary human hepatocytes and their induction in HepG2 cells. Toxicol in Vitro 21(8):1581-1591

79. Alghazeer R, Howell NK, El-Naili MB, Awayn N (2018) Anticancer and antioxidant activities of some algae from western Libyan coast. Nat Sci 10(7):232-246

80. Seetharaman S, Indra V, Selva Muthu B, Daisy A, Geetha S (2016) Phytochemical profiling and antibacterial potential of Kappaphycus alvarezii methanol extract against clinical isolated bacteria. World Journal of Pharmacy and Pharmaceutical sciences 5(6):1328-1337

81. Sujatha R, Siva D, Nawas, P.M.A. (2019) Screening of phytochemical profile and antibacterial activity of various solvent extracts of marine algae Sargassum swartzii. World Scientific News 115:2740

82. Naithani R, Huma LC, Holland LE, Shukla D, McCormick DL, Mehta RG, Moriartry RM (2008) Antiviral activity of phytochemicals: a comprehensive review. Mini-Rev Med Chem 8(11):1106-1133

83. Pereira HS, Leão-Ferreira LR, Moussatché N, Teixeira VL, Cavalcanti DN, Costa LJ, Diaz R, Frugulhetti ICCP (2004) Antiviral activity of diterpenes isolated from the Brazilian marine alga Dictyota menstrualis against human immunodeficiency virus type 1 (HIV-1). Antivir Res 64:69-76

84. Sayik A, Serguzel A, Yusufoglu AS, Acik L, Turker G, Aydin B, Arslan L (2017) DNA- binding, biological activities, and chemical composition of wild growing Epilobium angustifolium L. extracts from Canakkale, Turkey. Journal of Turkish Chemical Society 4(3): $811-840$

85. Patil A, Jadhav V (2014) GC-MS analysis of bioactive components from methanol leaf extract of Toddalia asiatica (L.). International Journal of Pharmaceutical Sciences Review and Research 29(1): $18-20$

86. Mebude OO, Adeniyi B (2017) GC-MS analysis of phyto components from the stem bark of Cola nitida Schott \& Endl. Journal of Plant Sciences 5(4):99-103

87. Kadri A, Zarai Z, Chobba IB, Gharsallah N, Damak M, Békir A (2011) Chemical composition and in vitro antioxidant activities of Thymelaea hirsuta L. essential oil from Tunisia. Afr J Biotechnol 10(15):2930-2935

88. Prakash A, Vuppu S (2014) Punica granatum (pomegranate) rind extract as a potent substitute for L-ascorbic acid with respect to the antioxidant activity. Res J Pharm, Biol Chem Sci 5(2):597-603

89. Cherchi G, Deidda D, De Gioannis B, Marongiu B, Pompei R, Porcedda S (2001) Extraction of Santolina insularis essential oil by supercritical carbon dioxide: influence of some process parameters and biological activity. Flavour and Fragrance Journal 16:3543

90. Kalaisezhiyen P, Sasikumar V (2012) GC- MS of chemical constituents from methanolic leaf extract of Kedrostis foetidissima (Jacq.) Cogn. Asian Journal of Pharmaceutical and Clinical Research 5(4): $77-81$

91. Mohamed AA, Ali SI, Darwesh OM, El-Hallouty SM, Sameeh MY (2015) Chemical compositions, potential cytotoxic and antimicrobial activities of Nitraria retusa methanolic extract sub-fractions. International Journal of Toxicological and Pharmacological Research 7(4):204-212

92. Srivastava R, Mukerjee A, Verma A (2015) GC-MS analysis of phytocomponents in, Pet ether fraction of Wrightia tinctoria seed. Pharm J 7(4):249-253

93. Abd El-Aty AM, Mohamed AA, Samhan FA (2014) In vitro antioxidant and antibacterial activities of two fresh water cyanobacterial species, Oscillatoria agardhii and Anabaena sphaerica. Journal of Applied Pharmaceutical Science 4(07):069-075

Publisher's note Springer Nature remains neutral with regard to jurisdictional claims in published maps and institutional affiliations. 